\title{
Is the distribution of Prochlorococcus and Synechococcus ecotypes in the Mediterranean Sea affected by global warming?
}

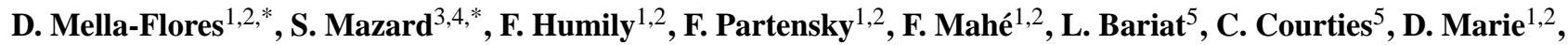 \\ J. Ras $^{6}$, R. Mauriac ${ }^{7}$, C. Jeanthon ${ }^{1,2}$, E. Mahdi Bendif ${ }^{1,2}$, M. Ostrowski ${ }^{3,4}$, D. J. Scanlan ${ }^{3}$, and L. Garczarek ${ }^{1,2}$ \\ ${ }^{1}$ CNRS, Observatoire Océanologique, UMR7144, Groupe Plancton Océanique, 29680 Roscoff, France \\ ${ }^{2}$ UPMC-Université Paris 06, Station Biologique, Place Georges Teissier, 29680 Roscoff, France \\ ${ }^{3}$ School of Life Sciences, University of Warwick, Coventry CV4 7AL, UK \\ ${ }^{4}$ Dept. Chemistry and Biomolecular Science, Macquarie University, North Ryde, NSW 2109, Australia \\ ${ }^{5}$ CNRS/INSU and UPMC-Université Paris 06, Laboratoire Arago, UMS2348, Observatoire Océanologique, \\ 66651 Banyuls-sur-mer, France \\ ${ }^{6}$ CNRS and UPMC-Université Paris 06, UMR7093, Laboratoire d'Océanographie de Villefranche, \\ 06234 Villefranche-sur-mer, France \\ ${ }^{7}$ Laboratoire d'océanographie physique et biogéochimique, Centre d'océanologie de Marseille, case 901, \\ campus de Luminy, 13288 Marseille cedex 09, France \\ *These two authors contributed equally to this work
}

Received: 8 April 2011 - Published in Biogeosciences Discuss.: 3 May 2011

Revised: 8 September 2011 - Accepted: 12 September 2011 - Published: 29 September 2011

\begin{abstract}
Biological communities populating the Mediterranean Sea, which is situated at the northern boundary of the subtropics, are often claimed to be particularly affected by global warming. This is indicated, for instance, by the introduction of (sub)tropical species of fish or invertebrates that can displace local species. This raises the question of whether microbial communities are similarly affected, especially in the Levantine basin where sea surface temperatures have significantly risen over the last 25 years $\left(0.50 \pm 0.11^{\circ} \mathrm{C}\right.$ in average per decade, $P<0.01)$. In this paper, the genetic diversity of the two most abundant members of the phytoplankton community, the picocyanobacteria Prochlorococcus and Synechococcus, was examined during two cruises through both eastern and western Mediterranean Sea basins held in September 1999 (PROSOPE cruise) and in June-July 2008 (BOUM cruise). Diversity was studied using dot blot hybridization with clade-specific 16S rRNA oligonucleotide probes and/or clone libraries of the 16S-23S ribosomal DNA Internal Transcribed Spacer (ITS) region, with a focus on the abundance of clades that may constitute bioindicators of warm waters. During both cruises, the dominant Prochlorococcus clade in the upper mixed layer at all stations was HLI, a clade typical of temperate waters, whereas the HLII clade, the dominant group in (sub)tropical waters, was only present at very low concentrations. The Synechococcus com-
\end{abstract}

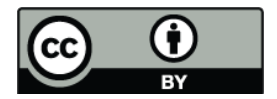

Correspondence to: L. Garczarek (laurence.garczarek@sb-roscoff.fr) munity was dominated by clades I, III and IV in the northwestern waters of the Gulf of Lions and by clade III and groups genetically related to clades WPC1 and VI in the rest of the Mediterranean Sea. In contrast, only a few sequences of clade II, a group typical of warm waters, were observed. These data indicate that local cyanobacterial populations have not yet been displaced by their (sub)tropical counterparts.

\section{Introduction}

Due to their ubiquity and abundance, marine cyanobacteria are widely recognized as being major contributors to global photosynthetic biomass and primary production (Campbell et al., 1994; Goericke and Welschmeyer, 1993; Li, 1994; Partensky et al., 1999). Two genera dominate the picophytoplankton size fraction $(0.2-2 \mu \mathrm{m})$, Prochlorococcus and Synechococcus. Although these genera co-occur in tropical and temperate areas, their abundance patterns differ not only spatially but also seasonally (Johnson et al., 2006; Tai and Palenik, 2009; Zwirglmaier et al., 2008). Indeed, Synechococcus prefers well-lit, nutrient-rich waters and usually blooms in spring when the water column is mixed, whereas Prochlorococcus is most abundant in oligotrophic waters and reaches maximal concentrations in summer and fall when waters are stratified, with a deeper sub-surface maximum than Synechococcus (Campbell et al., 1994; DuRand et al.,

Published by Copernicus Publications on behalf of the European Geosciences Union. 
2001; Lindell and Post, 1995). Both genera are culturable and this has considerably facilitated studies on their physiological and genetic diversity. Each comprises a number of clades or "ecotypes" (sensu Coleman and Chisholm, 2007) exhibiting distinct ecophysiologies and spatial distributions.

For Prochlorococcus, several different ecotypes coexist in the water column. The upper part of the euphotic zone is occupied by high light-adapted (HL) ecotypes. HLII (also called eMIT9312) dominates in permanently stratified waters from the equator to subtropics, and is progressively replaced at high latitude by HLI (also called eMED4; Johnson et al., 2006; Zwirglmaier et al., 2007; Zwirglmaier et al., 2008). The distinct latitudinal distribution pattern of Prochlorococcus HLI and HLII ecotypes is well supported by the different temperature ranges for growth of representative isolates (Johnson et al., 2006; Zinser et al., 2007). These complementary distributions make variations of the relative concentrations of these two HL ecotypes a good potential bioindicator of community shifts as a result of temperature changes of oceanic waters. Two further HL clades (HNLC1 and HNLC2) have recently been shown to occur specifically in warm, iron-depleted areas of the ocean, such as the eastern Equatorial Pacific upwelling and the tropical Indian Ocean (Rusch et al., 2010; West et al., 2010).

Until recently, it was thought that the bottom of the euphotic layer was dominated by the low light-adapted LLIV ecotype (also called eMIT9313), but recent evidence using qPCR analyses with refined ecotype-specific primers suggests that it co-occurs with the LLII ecotype (also called eSS120), and the latter one could even outnumber LLIV (Malmstrom et al., 2010). A fifth ecotype (LLI, also called eNATL) was found to occupy an intermediate niche in the water column, in the vicinity of the thermocline (Johnson et al., 2006; Zinser et al., 2006, 2007). Clone library sequencing has also revealed the presence of several additional but still uncultured LL clades, including NC1, a potentially abundant group found at depth at several stations of the Atlantic and Pacific oceans (Martiny et al., 2009), and two LL clades (LLV and LLVI) seemingly specific for low oxygen zones (Lavin et al., 2010). However, at high latitudes, the lower stability of the water column progressively simplifies these depth distribution patterns, since only HLI and LLI ecotypes appear able to survive in mixed, cool water conditions (Johnson et al., 2006).

For Synechococcus, some general distribution patterns can also be defined for several of the ten clades defined by Fuller et al. (2003), although the genetic and/or physiological bases behind these patterns are much less well understood than for Prochlorococcus. Clades I and IV generally co-occur at latitudes above $30^{\circ} \mathrm{N} / \mathrm{S}$ and seem to be restricted to near coastal waters in the lowest part of their latitudinal distributions (Tai and Palenik, 2009; Zwirglmaier et al., 2007, 2008; Mazard et al., 2011). In contrast, clade II seems to be abundant in warm, coastal or shelf areas and is thought to be the (sub)tropical counterpart of clades I/IV, although some overlap may oc- cur in the boundary zone, i.e. between $30^{\circ}$ and $35^{\circ}$, in both the southern and northern hemispheres (Zwirglmaier et al., 2008). The latitudinal distribution of clade III appears to be broader, but cells belonging to this ecotype seemingly prefer oligotrophic, offshore waters. All other clades are generally found at lower concentrations than clades I to IV and their distribution patterns are therefore less clearly defined (Zwirglmaier et al., 2008).

A number of recent studies have reported striking changes in the distribution and/or diversity of a variety of Mediterranean organisms, such as fish and marine invertebrates (for recent reviews, see Coll et al., 2010; Lejeusne et al., 2009). Indeed, it seems that more and more tropical or subtropical species are colonizing this marine area, often replacing local species (Bianchi, 2007). Whether the community structure of marine prokaryotes is also affected by environmental change, and in particular picocyanobacteria that are key players in the productivity of the Mediterranean Sea, has been little studied so far. In the present paper, we use dot blot hybridization analysis and/or clone library sequencing to analyze the vertical and horizontal distributions of Prochlorococcus and Synechococcus ecotypes/clades during two cruises in the Mediterranean Sea, PROSOPE and BOUM, held some nine years apart in the Mediterranean Sea and which followed comparable transects through both western and eastern basins.

\section{Methods}

\subsection{Sampling}

Water samples were collected at several stations during two independent cruises in the Mediterranean Sea, the PROSOPE cruise (Productivity of Oceanic Pelagic Systems) that was held from 9 September to 1 October, 1999 aboard the French research vessel R/V La Thalassa (for details on hydrology; see Garczarek et al., 2007; Marie et al., 2006; Crombet et al., 2011) and the BOUM cruise (Biogeochemistry from the Oligotrophic to the Ultra-oligotrophic Mediterranean) held from 22 June to 18 July, 2008 aboard the R/V L'Atalante (Fig. 1). Additional samples were collected at the BOUSSOLE site (located near the PROSOPE cruise DYF site; see Fig. 1) during the BOUSSOLE 88 cruise held on 15 June 2009 aboard the R/V Tethys II. At each station, 4 to 81 water samples were retrieved from 4 to 6 discrete depths using 121 Niskin bottles, fitted on a Seabird CTDO rosette sampler (model SBE 911) equipped with in situ conductivity, temperature, depth, oxygen as well as chlorophyll fluorescence sensors. Seawater was subsequently filtered through a $20 \mu \mathrm{m}$ meshed silk (Whatman Co.) and $47 \mathrm{~mm}$ diameter, $3 \mu \mathrm{m}$ pore size polycarbonate Nuclepore filters (Whatman, Maidstone, UK). Picoplanktonic cells were then collected by filtration onto $47 \mathrm{~mm}$ diameter, $0.2 \mu \mathrm{m}$ pore size Pall Supor-200 filters (Gelman Inc., Ann Arbor, MI). The 


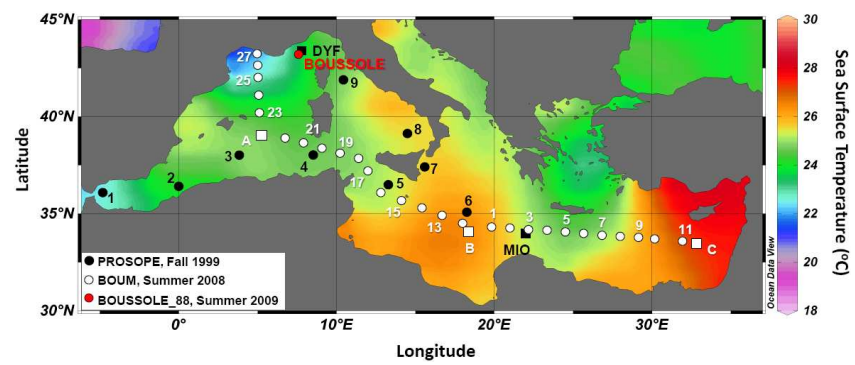

Fig. 1. False-color composite satellite image of sea surface temperature of the Mediterranean Sea in July 2008 (data: NOAA). The sampling stations of the PROSOPE, BOUM and BOUSSOLE 88 cruises, numbered in order of occupation, are indicated in black, white and red, respectively. Short- and long-term stations are indicated by dots and squares, respectively.

filter was transferred into a cryovial containing $1.8 \mathrm{ml}$ of DNA lysis buffer (20 mM EDTA, $400 \mathrm{mM} \mathrm{NaCl}, 0.75 \mathrm{mM}$ sucrose, $50 \mathrm{mM}$ Tris $\mathrm{pH} 9$ ), quickly frozen in liquid nitrogen and stored at $-80^{\circ} \mathrm{C}$ until extraction. At all stations and depths, samples were taken to determine nitrate and phosphate concentrations (Raimbault et al., 1990) and perform HPLC pigment analyses (Ras et al., 2008). Prochlorococcus and Synechococcus cell concentrations were measured by flow cytometry, as detailed previously (Marie et al., 1999; Obernosterer et al., 2008). Due to the dim fluorescence of Prochlorococcus cells in the upper mixed layer, populations were not completely resolved from the background noise at most stations, so that for integrating cell numbers up to the surface, we assumed that the concentration measured at the bottom of the mixed layer was the same throughout the top layer. All these data are available on-line on the BOUM cruise database (http://www.com.univ-mrs.fr/BOUM/).

\subsection{DNA extraction}

DNA was extracted from the filters largely following the method described by Massana et al. (2004) but with slight modifications. Briefly, filters from selected stations and depths were first cut into small pieces using clean scissors and resuspended by strong vortexing in lysis buffer, used as storage buffer. Samples were then incubated at $37^{\circ} \mathrm{C}$ for $45 \mathrm{~min}$ in the presence of lysozyme at a final concentration of $1 \mathrm{mg} \mathrm{ml}^{-1}$, then $1 \mathrm{~h}$ at $50^{\circ} \mathrm{C}$ with proteinase $\mathrm{K}$ and SDS (final concentrations of $0.2 \mathrm{mg} \mathrm{ml}^{-1}$ and $1 \% \mathrm{w} / \mathrm{v}$, respectively). Nucleic acids were extracted consecutively with phenol:chloroform:isoamyl alcohol (25:24:1) and chloroform:isoamyl alcohol (24:1) before being precipitated with $2.5 \mathrm{vol}$ of $100 \%(\mathrm{v} / \mathrm{v})$ cold ethanol and $0.1 \mathrm{vol}$ of $3 \mathrm{M}$ sodium acetate (pH 5.2) at $-20^{\circ} \mathrm{C}$. Nucleic acids were recovered by centrifugation, washed twice with $70 \%$ ethanol (v/v), resuspended in sterile water and stored at $-80^{\circ} \mathrm{C}$.

Strains representative of the different Prochlorococcus and Synechococcus clades, obtained from the Roscoff Culture
Collection (RCC, http://www.sb-roscoff.fr/Phyto/RCC/) or held at Warwick University, were used as controls in dot blot hybridization experiments (Table 1). Their DNA was extracted as described by Eguchi et al. (2001). Briefly, $50 \mathrm{ml}$ of late logarithmic phase cells were pelleted and then resuspended in $567 \mu$ of TE buffer $(10 \mathrm{mM}$ Tris- $\mathrm{HCl} \mathrm{pH} 8,1 \mathrm{mM}$ EDTA). Cells were lysed at $60^{\circ} \mathrm{C}$ for $4 \mathrm{~h}$ after addition of SDS $(0.5 \% \mathrm{w} / \mathrm{v}$ final $)$ and proteinase $\mathrm{K}\left(250 \mathrm{mg} \mathrm{ml}^{-1}\right.$ final). $\mathrm{NaCl}(100 \mu \mathrm{l}$ of $5 \mathrm{M})$ and CTAB $(80 \mu \mathrm{l}$ of $10 \% \mathrm{w} / \mathrm{v}$ hexadecyltrimethyl ammonium bromide in $0.7 \mathrm{M} \mathrm{NaCl}$; SigmaAldrich, St Louis, MO, USA) were added and mixed thoroughly and samples incubated at $65^{\circ} \mathrm{C}$ for $10 \mathrm{~min}$. Nucleic acids were purified from CTAB complexes by successive chloroform:isoamyl alcohol $(24: 1 ; 1 \mathrm{vol})$ and phenol:chloroform:isoamyl alcohol $(25: 24: 1 ; 1 \mathrm{vol})$ extractions before being precipitated by addition of $0.6 \mathrm{vol}$ isopropanol. Nucleic acids were then purified successively in 50\%,70\% and $100 \%(\mathrm{v} / \mathrm{v})$ ethanol, resuspended in sterile water and kept at $-20^{\circ} \mathrm{C}$ for further use. The quality and quantity of environmental or strain DNA was monitored using a Nanodrop ND-1000 spectrophotometer (NanoDrop Technologies, Wilmington, USA).

\subsection{PCR amplification for dot blot hybridization analysis}

16S rDNA sequences were amplified from control strains and environmental DNA using the primers OXY107F (GGACGGGTGAGTAACGCGTG) and OXY1313R (CTTCAYGYAGGCGAGTTGCAGC), which specifically target sequences from oxygenic phototrophs (Fuller et al., 2003).

PCR reactions were carried out in a total reaction volume of $100 \mu \mathrm{l}$ with $1.0-10 \mathrm{ng}$ of template DNA per reaction. The reaction mix consisted of $200 \mathrm{nM}$ forward and reverse primers, $200 \mu \mathrm{m}$ dNTPs, $2.0 \mathrm{mM} \mathrm{MgCl}_{2}$ and $2.5 \mathrm{U}$ of Taq DNA polymerase (Qiagen, Valencia, CA). For amplification of environmental DNAs, BSA (bovine serum albumin, Sigma-Aldrich, St Louis, MO, USA) was added at $1.0 \mathrm{mg} \mathrm{ml}^{-1}$ and hot start PCR was routinely performed. The reaction cycle consisted of an initial denaturation step of $4 \mathrm{~min}$ at $96^{\circ} \mathrm{C}$ and $1 \mathrm{~min}$ at $80^{\circ} \mathrm{C}$, then primers, dNTPs and Taq were added to the reaction mix, followed by $25-30 \mathrm{cy}-$ cles of $94^{\circ} \mathrm{C}$ for $45 \mathrm{~s}, 55^{\circ} \mathrm{C}$ for $30 \mathrm{~s}, 72^{\circ} \mathrm{C}$ for $1 \mathrm{~min}$, with a final extension at $72^{\circ} \mathrm{C}$ for $6 \mathrm{~min}$. PCR products were purified using the Qiaquick PCR purification kit (Qiagen, Valencia, CA) according to the manufacturer's instructions. The amplification reaction was repeated until sufficient DNA amount was available for each sample. PCR products were then pooled for dot blot hybridization analysis.

\subsection{Dot blot hybridization}

Hybridization conditions were as previously described (Fuller et al., 2003; West and Scanlan, 1999). Briefly, 
Table 1. Characteristics of 16S rDNA oligonucleotide probes used for dot blot hybridization. Abbreviations: Syn., Synechococcus; Proc., Prochlorococcus; n.a., not applicable.

\begin{tabular}{|c|c|c|c|c|c|c|}
\hline Probe names & Sequence $\left(5^{\prime}-3^{\prime}\right)$ & $\begin{array}{c}\text { Wash } \\
\text { Temp. }\left({ }^{\circ} \mathrm{C}\right)\end{array}$ & Target group & Reference genome $^{1}$ & Control sample ${ }^{2}$ & References \\
\hline EUB338 & GCTGCCTCCCGTAGGAGT & 46 & Eubacteria & n.a. & all & (Amann et al., 1990) \\
\hline SYN1006 & CTCTCAAGTTTCCAAGAG & 44 & Syn. clade I & CC9311 & CC9311 & (Fuller et al., 2003) \\
\hline SYN1006RS & СТCTCCTGTTTCCAAGAG & 42 & Syn. clade II & CC9605 & RS9903 & Idem \\
\hline SYN262 & GATGCCTTGGTAGGCCTT & 53 & Syn. clade III & WH8102 & WH8103 & Idem \\
\hline SYN635 & AAGCCCCTCAGTTTCCAC & 50 & Syn. clade IV & BL107, CC9902 & $5 \times 15$ & Idem \\
\hline SYN1280 & GAGCCACGGTTTATGAGA & 51 & Syn. clade V/VI/VII & WH7803/WH7805/- & WH7803/WH8018/ MITS9220 & Idem \\
\hline SYN620 & CACTGCCACGATGGAGTT & 51 & Syn. clade VIII & RS9917 & RS9913 & Idem \\
\hline SYN1000 & GGTTTCCCAGAAATTCGC & 45 & Syn. clade IX & RS9916 & RS9916 & Idem \\
\hline SYN1007 & ACCCTCCGGTTTCCCAGA & 48 & Syn. clade $\mathrm{X}^{3}$ & RCC307 & RCC307 & idem \\
\hline S2PRO640R & ATACTCAAGCCTTTCAGTTT & 41 & Proc. HLII & MIT9312 & TAK9803-2 & (Zwirglmaier et al., 2007) \\
\hline S1PRO634R & GCCGATCAGTTTCCACTG & 50 & Proc. HLI & MED4 & PCC9511 & (West and Scanlan, 1999) \\
\hline DPRO634R & GCCAATCAGTTTCCACTG & 46 & Proc. LLI/LLIV & NATL1/MIT9313 & NATL1/MIT9303 & Idem \\
\hline SARG634R & GCCCTTCAGTTTCCACTG & 44 & Proc. LLII & SS120 & SS120 & idem \\
\hline
\end{tabular}

${ }^{1}$ Reference strain (with sequenced genome) representative of the target group, when available (Dufresne et al., 2008).

${ }^{2}$ Strains (or environmental sample in the case of clade IV) representative of the target group and used here as controls for dot blot hybridizations. DNA from the same samples was also used to draw hybridization curves for each probe (cf. materials and methods).

${ }^{3}$ Now called sub-cluster 5.3 (Dufresne et al., 2008).

oligonucleotide probes (30 ng, dual HPLC grade purified) targeting each Prochlorococcus and Synechococcus clade (Table 1) were end-labeled with $\gamma^{32} \mathrm{P}$-ATP using T4 polynucleotide kinase in $1 \mathrm{X}$ forward kinase buffer (Invitrogen, Carlsbad, CA) at $37^{\circ} \mathrm{C}$ for $1 \mathrm{~h}$. Unincorporated nucleotides were then removed by purification through a mini Quick Spin DNA Column (Roche, Basel, Switzerland). Purified 16S rDNA amplicons from BOUM environmental DNA and control strains were blotted onto Zeta-Probe nylon membranes using a Bio-Dot microfiltration apparatus (both from BioRad, Laboratories Ltd., Hemel Hempstead, Herts, UK) and hybridized with labeled clade-specific oligonucleotide probes as described previously (Fuller et al., 2003; see Table 1). Hybridization signals were quantified using a Phosphorimager (Typhoon Trio) and ImageQuant TL software (both from GE Healthcare, Buckinghamshire, UK).

Relative hybridization of clade-specific probes to total oxygenic phototroph 16S rDNA sequences were calculated as described previously (Fuller et al., 2003) by normalizing the individual Prochlorococcus and Synechococcus probe signals to the signal for total amplified DNA, as determined with the EUB338 probe. The dot blot hybridization data as well as other environmental parameters were visualized using the Ocean Data View software, designed by R. Schlitzer (http://odv.awi.de).

\subsection{Clone libraries and phylogenetic analyses}

16S-23S ribosomal DNA Internal Transcribed Spacer (hereafter ITS) regions were amplified using the 16S-1247f (CGTACTACAATGCTACGG) and 23S-241r (TTCGCTCGCCRCTACT) primer set (Rocap et al., 2002). PCR reactions were performed in $25 \mu \mathrm{l}$ volumes containing $1.25 \mathrm{U}$ Taq polymerase (Promega, Madison, WI), 1X buffer provided with the polymerase, $1.5 \mathrm{mM} \mathrm{MgCl} 2,1.25 \mathrm{mM}$ of each dNTP, $0.5-1 \mu \mathrm{m}$ of each primer and $0.5-1 \mu \mathrm{l}$ of environmental DNA template. The reaction cycle consisted of an initial denaturation step of $5 \mathrm{~min}$ at $95^{\circ} \mathrm{C}$, followed by $25-30$ cycles of $1 \mathrm{~min}$ at $94{ }^{\circ} \mathrm{C}, 1 \mathrm{~min}$ at $52^{\circ} \mathrm{C}$ and 2 min at $72^{\circ} \mathrm{C}$ with a final extension at $72^{\circ} \mathrm{C}$ for $10 \mathrm{~min}$. To minimize PCR biases, the number of PCR cycles was adjusted between 25 to 30 cycles in order to obtain a very faint band on agarose gels. Ten parallel reactions were performed for each sample followed by a three-cycle reconditioning step (Thompson et al., 2002) by transferring $2.5 \mu \mathrm{l}$ each of the initial reaction mixture into $22.5 \mu \mathrm{l}$ of fresh PCR mixture. PCR products were then pooled, purified using the Qiaquick kit PCR purification kit (Qiagen, Valencia, CA) and cloned using the TOPO TA cloning kit (Invitrogen, Carlsbad, CA). The presence of an insert was screened by PCR amplification of colonies using the vector specific M13 primers. The size of inserts, as measured by agarose gel electrophoresis, was also used to specifically enrich Synechococcus sequences since the ITS sequence is generally longer in Synechococcus than in Prochlorococcus (except LLIV strains; Rocap et al., 2002). Between 69-80 clones from each sample were sequenced bidirectionally on an ABI3130 automated sequencer using Big Dye terminator Cycle sequencing kits version 3.0 (both from Applied Biosystems, Foster City, CA), according to the manufacturer's instructions.

A total of 746 environmental ITS sequences were obtained. In further analysis of these sequences primer regions were excluded. To avoid redundancy, only 149 sequences, including only one sequence per cd-hit cluster, as defined with a percent identity cutoff of $99 \%$ (Li and Godzik, 2006), and all BOUM sequences from the four new clades described in this study, were deposited in the Genbank nucleotide sequence database under the following accession numbers: 
JN006522-JN006718. Their phylogenetic affiliation was determined using Pplacer v1.0, which places sequences into a reference tree (Matsen et al., 2010). First, a reference alignment of full-length ITS sequences was made with 97 selected sequences of isolates and environmental clones representative of the whole diversity of Synechococcus and Prochlorococcus clades/ecotypes known so far, including four novel groups that were revealed by preliminary phylogenetic analyses of our own sequences (see results). The alignment was done using MAFFT v6.847 taking into account the RNA secondary structure (Q-INS-i option; Katoh and Toh, 2008), then manually refined using BioEdit v7.0.5.3 (Hall, 1999). The general time-reversible $(G T R+I+G)$ model of nucleotide substitution was selected according to JModeltest v0.1.1 (Posada, 2008) and the corrected Akaike information criterion (Posada, 2009) for the phylogenetic inference of each sequence by Maximum Likelihood (ML) using PhyML v3.0 (Guindon and Gascuel, 2003) with gamma and invariant sites distributions.

Environmental sequences were then aligned with a HMM built from the reference alignment using tools from the HMMER v3.0 suite (http://hmmer.janelia.org/), with default parameters. Using this alignment and the reference tree, the most probable location for each environmental sequence was determined using Pplacer and this was visualized by additional branches in the tree (see Fig. S2 in the Supplement). The same affiliation of environmental sequences was obtained with two independent methods (not shown): (i) a clustering strategy based on pairwise-distances between reference and environmental sequences (Needleman-Wunsch algorithm as implemented in Emboss; Needleman and Wunsch, 1970) and (ii) a strategy based on maximum likelihood analyses of a large multiple sequence alignment including both reference and environmental sequences using RaxML (Stamatakis, 2006).

While a full-length ITS sequence reference alignment was necessary for Pplacer, phylogenetic analyses were performed after removing a number of hypervariable regions and gaps, leaving a total of 1135 positions, including tRNAs. Bayesian inference was then conducted using $\mathrm{Mr}$ Bayes v3.1.2 (Huelsenbeck and Ronquist, 2001), starting with a random tree, run two million generations in four chains and with a burn-in of 2000 generations, using parameters similar to the ML method. Neighbor-Joining (NJ) based on the F84 distance model and Maximum Parsimony (MP) trees were inferred using Phylip v3.69 (Felsenstein, 1989). Robustness of inferred topology was supported by bootstrap resampling (1000) with ML, NJ and MP. Very similar tree topologies were obtained for the full-length and the cut versions of the reference alignment except for slight modifications of the relative position of a few groups, essentially within sub-cluster 5.1B (see results).

\section{Results}

\subsection{Hydrology}

The Mediterranean Sea is a semi-enclosed sea undergoing extensive water mixing during winter, a seasonal phenomenon that injects nutrients from deep waters into surface waters (Marty et al., 2002). These nutrients are rapidly consumed by phytoplankton during late winter/early spring blooms, which occur in surface waters in the northern Mediterranean Sea (as seen by satellite imagery; D'Ortenzio and Ribera d'Alcala, 2009) and at depth further south (Crombet et al., 2011). By early summer, the upper mixed layer becomes oligotrophic and the chlorophyll biomass reaches annual minima over the whole Mediterranean Sea (D'Ortenzio and Ribera d'Alcala, 2009).

Figure $2 \mathrm{a}-\mathrm{c}$ shows high resolution plots of the vertical distribution of temperature, salinity and fluorescence along the BOUM cruise transect held in late June-early July 2008. These graphs show the occurrence of a strong vertical thermal stratification along the whole transect (Fig. 2a) and a strong horizontal salinity gradient increasing from $\mathrm{W}$ to $\mathrm{E}$ (Fig. 2b), with a marked halocline located in the Ionian Sea. This gradient separates western Atlantic waters entering the Mediterranean Sea in the Straits of Gibraltar, from the high salinity waters of the east Mediterranean Sea. Also notable is the progressive eastwards deepening of the fluorescence maximum (Fig. 2c), a proxy for the deep chlorophyll maximum (DCM), associated with a comparable deepening of nutriclines (not shown, but see Crombet et al., 2011; Pujo-Pay et al., 2011). These summertime hydrological characteristics were globally similar to those previously reported for the PROSOPE cruise in late summer-early fall (Garczarek et al., 2007; Marie et al., 2006), including sea surface temperatures (SST) above $24{ }^{\circ} \mathrm{C}$ (except at the three northernmost stations of BOUM and the westernmost station of PROSOPE), and comparable depths of the upper mixed layer $(25-30 \mathrm{~m})$ in the common parts of both cruises. The most notable hydrological difference between the two cruises was the position of the halocline, located more eastward during BOUM (in the Ionian Sea) than during PROSOPE (off the Algerian coasts; Garczarek et al., 2007).

SST data for the 1985-2010 period were retrieved from the National Oceanic and Atmospheric Administration (http: //iridl.ldeo.columbia.edu/SOURCES/.NOAA/; Reynolds et al., 2002) in order to calculate the summer SST anomaly for the same period, i.e. the difference between the average SST for the three warmest months (July, August and September) of any given year and the mean summer SST averaged over the last 25 years. Figure 3 shows both the monthly SST variations and the evolution of summer SST anomalies in the $1^{\circ}$ latitude-longitude grid areas surrounding the three long-term stations (hereafter Sta.) of the BOUM cruise. The latter stations were in the middle of three anticyclonic eddies, located in the Algero-Provencal basin (Sta. A), 

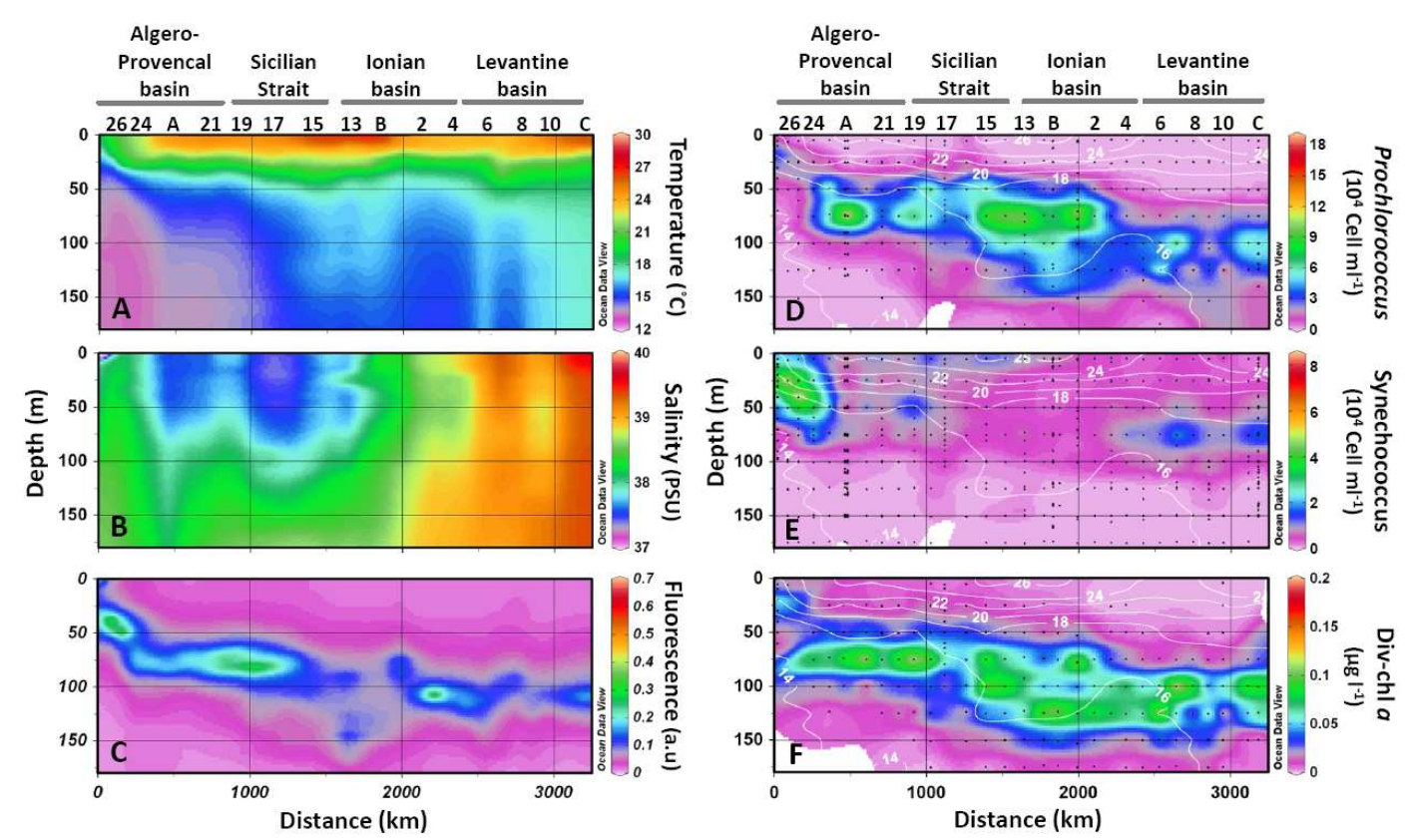

Fig. 2. Depth profiles of temperature (A), salinity (B), fluorescence (C), Prochlorococcus abundance (D), Synechococcus abundance (E) and concentration of the Prochlorococcus-specific pigment divinyl-Chl $a(\mathbf{F})$ along the BOUM cruise track. For each panel, the $x$ axis represents the cumulative distance in kilometers from a site near the French coast $\left(43.21^{\circ} \mathrm{N}, 4.93^{\circ} \mathrm{E}\right)$ and the y axis represents depth in meters. The positions of the main marine regions are indicated at the top of the graph as well as the number (or letter) of every two stations along the transect. For figures (D) to (F), white contour lines represent temperature in ${ }^{\circ} \mathrm{C}$ and black dots correspond to sampled depths. Note that to better emphasize the differential distributions of Prochlorococcus and Synechococcus along the BOUM transect, different scales have been used in Fig. 2d and e.

the Ionian basin (Sta. B) and the Levantine basin (Sta. C). Over this 25-year period, the SST measured during the coldest (March) and warmest (August) months showed no significant trend at Sta. A, whereas at Sta. B and C, SST increased for both March and August (Fig. 3a-c). Similarly, the summer SST anomaly showed a significant trend only in the eastern Mediterranean Sea (Fig. 3d-f), with the strongest rate of increase $\left(0.050 \pm 0.011^{\circ} \mathrm{C}\right.$ per year, $\left.P<0.01\right)$ observed at the easternmost Sta. C (Fig. 3f). It must be noted though that when considering only the period between the two cruises (1999-2008), there were no significant SST increase at the latter station.

\subsection{Vertical distributions of marine picocyanobacteria}

Figure 2d-e shows the vertical distributions of Prochlorococcus and Synechococcus during the BOUM cruise, as determined by flow cytometric cell counting. The highest Synechococcus abundances (range: $3.5-8.3 \times 10^{4}$ cells ml $^{-1}$; Table 2) were observed in subsurface, mesotrophic waters of the Gulf of Lions, i.e. at the northernmost stations of the Algero-Provencal basin (Sta. 25-27), and the depth of maximum abundance progressively increased southwards to reach $75 \mathrm{~m}$ at Sta. A. From Sta. 22 to 18, fairly high Synechococcus abundances (range: $0.63-1.93 \times 10^{4}$ cells ml$^{-1}$ ) were found down to $50 \mathrm{~m}$, whereas from the Sicily Strait (Sta. 17) to
Sta. B cell densities dropped very rapidly with depth, with typically a 2- to 3 -fold decrease between surface (ca. $5 \mathrm{~m}$ ) and $25 \mathrm{~m}$ waters. Comparatively, in the same area during the PROSOPE cruise (Sta. 5 and 6), surface abundances of Synechococcus were about two-fold higher than on the BOUM cruise and fairly high cell densities $\left(>10^{4}\right.$ cells ml $\left.{ }^{-1}\right)$ were observed down to $70 \mathrm{~m}$ (Garczarek et al., 2007). East of BOUM Sta. 3, the Synechococcus maximum systematically occurred around $75 \mathrm{~m}$, i.e. about $25 \mathrm{~m}$ above the DCM (Table 2). Since the PROSOPE transect did not extend as far east as the BOUM cruise, it is not possible to say whether this marked deep Synechococcus maximum, possibly related to the extreme oligotrophy of the upper layer in the eastern Mediterranean Sea waters, already existed in 1999 (but see Fig. 5d in Tanaka et al., 2007, for a profile made in May 2002). In terms of integrated Synechococcus concentrations, the highest value of the BOUM cruise occurred at Sta. $25\left(2.50 \times 10^{8}\right.$ cells cm $\left.^{-2}\right)$ and the lowest at Sta. B $\left(2.81 \times 10^{7}\right.$ cells cm${ }^{-2}$; Table 2$)$, consistent with the very different nutrient regimes of these two stations (Crombet et al., 2011).

For Prochlorococcus, the highest abundance during the whole BOUM cruise was observed at Sta. 1 at a depth of

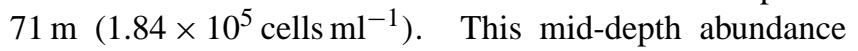
maximum extended over most of the transect from Sta. A 
Table 2. Maximal and integrated concentrations of Prochlorococcus and Synechococcus at each station of BOUM and PROSOPE cruises.

\begin{tabular}{|c|c|c|c|c|c|c|c|c|}
\hline Cruise & Station & $\begin{array}{l}\text { DCMD } \\
(\mathrm{m})\end{array}$ & $\begin{array}{l}\text { MAC Proc. } \\
\text { (cells ml }^{-1} \text { ) }\end{array}$ & $\begin{array}{l}\text { MAD Proc. } \\
\text { (m) }\end{array}$ & $\begin{array}{c}\text { IC Proc. } \\
\text { (cells cm }{ }^{-2} \text { ) }\end{array}$ & $\begin{array}{l}\text { MAC Syn. } \\
\left(\text { cells } 1^{-1}\right)\end{array}$ & $\begin{array}{l}\text { MAD Syn. } \\
\text { (m) }\end{array}$ & $\begin{array}{c}\text { IC Syn. } \\
(\text { cells cm } \\
\text { (-2) }\end{array}$ \\
\hline \multirow{23}{*}{ BOUM } & 27 & 30 & $5.19 \mathrm{E}+04$ & 19 & $1.60 \mathrm{E}+08$ & $3.54 \mathrm{E}+04$ & 10 & $1.23 \mathrm{E}+08$ \\
\hline & 26 & 37 & $1.05 \mathrm{E}+04$ & 25 & n.a. & $8.35 \mathrm{E}+04$ & 25 & $2.38 \mathrm{E}+08$ \\
\hline & 24 & 71 & $3.85 \mathrm{E}+04$ & 51 & $2.07 \mathrm{E}+08$ & $3.23 \mathrm{E}+04$ & 51 & $2.07 \mathrm{E}+08$ \\
\hline & 23 & 75 & $1.01 \mathrm{E}+05$ & 50 & $4.30 \mathrm{E}+08$ & $3.05 \mathrm{E}+04$ & 50 & $1.74 \mathrm{E}+08$ \\
\hline & A & 88 & $1.38 \mathrm{E}+05$ & 75 & $5.60 \mathrm{E}+08 \pm 1.13 \mathrm{E}+08(n=15)$ & $1.01 \mathrm{E}+04$ & 75 & $4.0 \mathrm{E}+07 \pm 5.93 \mathrm{E}+06(n=21)$ \\
\hline & 20 & 78 & $7.56 \mathrm{E}+04$ & 76 & $3.66 \mathrm{E}+08$ & $1.28 \mathrm{E}+04$ & 51 & $8.93 \mathrm{E}+07$ \\
\hline & 19 & 67 & $7.43 \mathrm{E}+04$ & 76 & $2.99 \mathrm{E}+08$ & $1.93 \mathrm{E}+04$ & 51 & $8.80 \mathrm{E}+07$ \\
\hline & 18 & 81 & $8.97 \mathrm{E}+04$ & 51 & $5.67 \mathrm{E}+08$ & $1.73 \mathrm{E}+04$ & 5.2 & $1.15 \mathrm{E}+08$ \\
\hline & 17 & 77 & $4.74 \mathrm{E}+04$ & 65 & $3.61 \mathrm{E}+08$ & $8.82 \mathrm{E}+03$ & 6.0 & $6.71 \mathrm{E}+07$ \\
\hline & 16 & 73 & $5.58 \mathrm{E}+04$ & 51 & $2.96 \mathrm{E}+08$ & $8.42 \mathrm{E}+03$ & 5.3 & $4.30 \mathrm{E}+07$ \\
\hline & 15 & 98 & $1.06 \mathrm{E}+05$ & 76 & $8.08 \mathrm{E}+08$ & $1.35 \mathrm{E}+04$ & 5.1 & $6.47 \mathrm{E}+07$ \\
\hline & 14 & 118 & $1.00 \mathrm{E}+05$ & 75 & $6.35 \mathrm{E}+08$ & $1.16 \mathrm{E}+04$ & 4.9 & $3.78 \mathrm{E}+07$ \\
\hline & 2 & n.a. & $5.67 \mathrm{E}+04$ & 100 & $5.66 \mathrm{E}+08$ & $6.47 \mathrm{E}+03$ & 75 & $4.70 \mathrm{E}+07$ \\
\hline & 3 & 104 & $4.02 \mathrm{E}+04$ & 125 & $2.38 \mathrm{E}+08$ & $7.38 \mathrm{E}+03$ & 50 & $5.90 \mathrm{E}+07$ \\
\hline & 4 & 98 & $2.13 \mathrm{E}+04$ & 101 & $1.93 \mathrm{E}+08$ & $1.43 \mathrm{E}+04$ & 75 & $7.14 \mathrm{E}+07$ \\
\hline & 5 & 114 & $6.94 \mathrm{E}+04$ & 100 & $2.57 \mathrm{E}+08$ & $1.55 \mathrm{E}+04$ & 75 & $5.43 \mathrm{E}+07$ \\
\hline & 6 & 117 & $8.75 \mathrm{E}+04$ & 125 & 4.07E+08 & $9.28 \mathrm{E}+03$ & 75 & $6.17 \mathrm{E}+07$ \\
\hline & 7 & 104 & $9.38 \mathrm{E}+04$ & 101 & $2.59 \mathrm{E}+08$ & $2.42 \mathrm{E}+04$ & 76 & $1.41 \mathrm{E}+08$ \\
\hline & 8 & 98 & $3.68 \mathrm{E}+04$ & 100 & $3.30 \mathrm{E}+08$ & $1.60 \mathrm{E}+04$ & 76 & $7.91 \mathrm{E}+07$ \\
\hline & 9 & 128 & $4.83 \mathrm{E}+04$ & 121 & $2.73 \mathrm{E}+08$ & $9.55 \mathrm{E}+03$ & 76 & $6.47 \mathrm{E}+07$ \\
\hline & 10 & 108 & $4.34 \mathrm{E}+04$ & 100 & $3.65 \mathrm{E}+08$ & $1.02 \mathrm{E}+04$ & 75 & $5.56 \mathrm{E}+07$ \\
\hline & 11 & 109 & $6.35 \mathrm{E}+04$ & 100 & $3.96 \mathrm{E}+08$ & $1.31 \mathrm{E}+04$ & 75 & $6.34 \mathrm{E}+07$ \\
\hline & $\mathrm{C}$ & 108 & $5.86 \mathrm{E}+04$ & 100 & $2.73 \mathrm{E}+08 \pm 4.076 \mathrm{E}+07(n=23)$ & $1.81 \mathrm{E}+04$ & 75 & $6.61 \mathrm{E}+07 \pm 1.11 \mathrm{E}+07(n=23)$ \\
\hline \multirow{2}{*}{ PROSOPE } & 1 & 49 & $4.54 \mathrm{E}+04$ & 29 & $2.54 \mathrm{E}+08$ & $9.89 \mathrm{E}+04$ & 49 & $5.64 \mathrm{E}+08$ \\
\hline & 2 & 40 & $3.80 \mathrm{E}+04$ & 29 & $1.67 \mathrm{E}+08$ & $5.61 \mathrm{E}+04$ & 15 & $2.49 \mathrm{E}+08$ \\
\hline
\end{tabular}

Abbreviations: DCMD, Deep Chlorophyll Maximum Depth; MAC, Maximum Abundance Concentration; MAD, Maximum Abundance Depth; IC, Integrated Concentration over the top 200 m; Syn., Synechococcus ; Proc., Prochlorococcus; n.a., not available; n, number of samples used to calculate the mean and standard deviation.

(Algero-Provencal basin) to Sta. 1 (Ionian Sea). At Sta. B, the most oligotrophic station of the transect (i.e., exhibiting the lowest integrated nitrate and phosphate concentrations over the top $150 \mathrm{~m}$ layer; see Moutin et al., 2002), the layer of high Prochlorococcus cell abundance extended very deeply, with average values as high as $4.7 \times 10^{4}$ cells ml $\mathrm{m}^{-1}$ at $140 \mathrm{~m}$. East of Sta. 1, the Prochlorococcus abundance maximum progressively deepened down to $100 \mathrm{~m}$ with a concomitant decrease of cell densities (Table 2 and Fig. 2d). The maximum concentration of Prochlorococcus specific pigment divinyl-Chl $a$ followed a similar trend, though it was sometimes deeper in the Ionian basin, likely due to strong photoacclimation in these very transparent, ultra-oligotrophic waters (Fig. 2f). In terms of integrated Prochlorococcus concentrations, the highest value of the BOUM cruise occurred at Sta. $15\left(8.08 \times 10^{8}\right.$ cells $\left.\mathrm{cm}^{-2}\right)$ and the lowest at Sta. 25 $\left(6.23 \times 10^{7}\right.$ cells $\mathrm{cm}^{-2}$; Table 2$)$.

\subsection{Distribution of picocyanobacterial lineages in the Mediterranean Sea}

\subsubsection{Prochlorococcus}

The distribution of the main Prochlorococcus ecotypes at selected stations of the BOUM cruise (Fig. 4) and at Station BOUSSOLE (sampled in June 2009; see Fig. S1 in the Supplement), was analyzed by dot blot hybridization using $16 \mathrm{~S}$ rRNA-targeted oligonucleotides. Results showed that over the whole transect, the dominant HL ecotype was HLI, whereas HLII was present at very low concentrations. Analysis of the depth distribution of HLI showed that its peak 

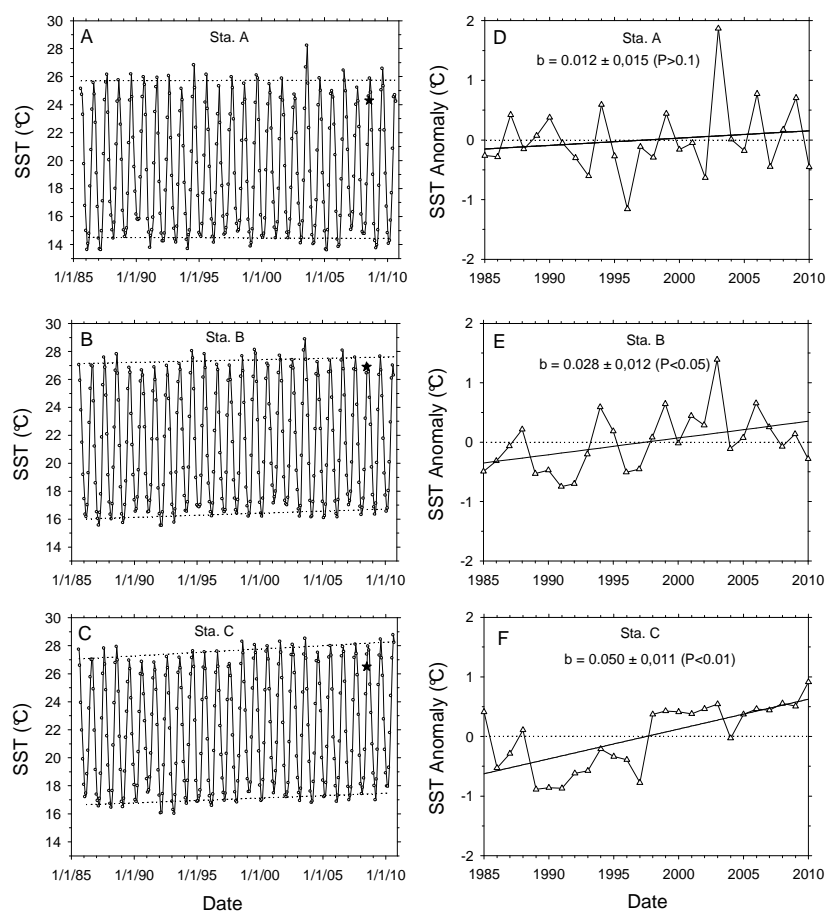

Fig. 3. Time plots over the $1985-2010$ period of sea surface temperature (SST) as measured by satellite $(\mathbf{A}, \mathbf{B}, \mathbf{C})$ and average SST anomaly for the three summer months $(\mathbf{D}, \mathbf{E}, \mathbf{F})$ in the $1^{\circ}$ latitudelongitude grid around the long term stations of the BOUM cruise (Sta. A, B and C; data: NOAA). The 25-year trend for the coldest (March) and warmest (August) months (dotted lines) and the actual SST measured on board during the BOUM cruise (stars) are indicated on plots A-C. The trend curve (plain line) and corresponding slope (b) and P-values are shown on plots $\mathbf{E}-\mathbf{F}$.

abundance generally occurred around $25 \mathrm{~m}$ in the western basin and $75 \mathrm{~m}$ in the eastern basin (except at Sta. 5) then rapidly decreased below these depths. Deep Prochlorococcus populations were dominated by LL ecotypes belonging to the LLI and/or LLIV clades; the oligonucleotide probe used here did not allow us to discriminate between these two populations, but previous studies have shown that LLI (eNATL) occurs at mid-depth (generally at the base of the thermocline) and LLIV (eMIT9313) at the bottom of the euphotic zone (Johnson et al., 2006; Zinser et al., 2006). At Sta. 13, the vertical distribution of LL ecotypes exhibited two clearly separated abundance maxima (with the upper one likely dominated by LLI and the bottom one by LLIV), a feature apparently related to an anomaly in the hydrological structure. Indeed, a low-salinity/high-nutrient layer was observed at $50 \mathrm{~m}$, probably due to a recent event of downwelling of modified Atlantic Waters below Mediterranean waters (see Fig. 2b for salinity and Crombet et al., 2011, for nutrients). The Prochlorococcus LLII (eSS120) ecotype was only abundant in the northwestern part of the Mediterranean Sea, BOUM Sta. 25 and Sta. BOUSSOLE, where notable hy-

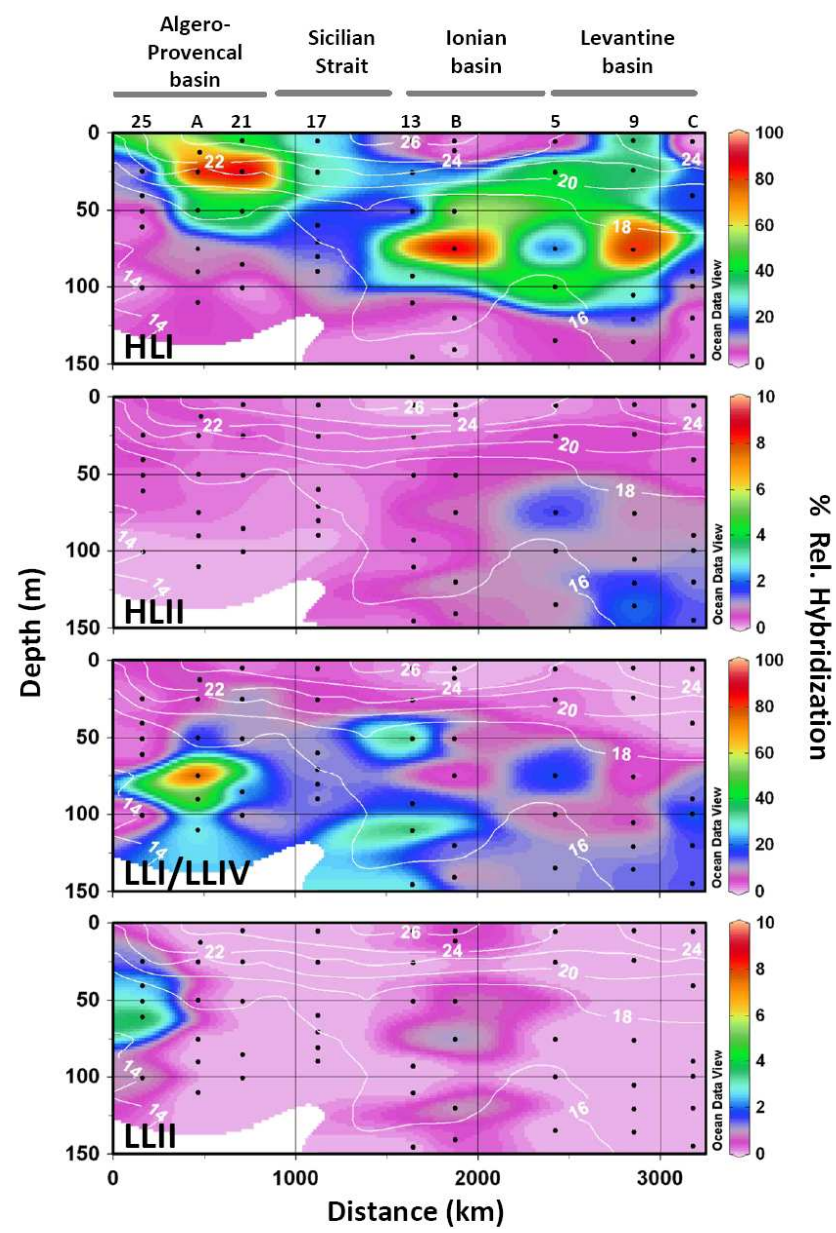

Fig. 4. Vertical distribution of Prochlorococcus ecotypes along the BOUM cruise track analyzed by dot blot hybridization using 16S rRNA gene specific oligonucleotide probes targeting HLI (high light ecotype I or eMED4), HLII (high light ecotype II or eMIT9312), LLI/LLIV (low light ecotypes I or eNATL and IV or eMIT9313) and LLII (low light ecotype II or eSS120). Contour plots indicate the $\%$ relative hybridization. The positions of the main marine regions are indicated at the top of the graph as well as the number (or letter) of the stations that have been sampled for dot blot hybridization. Details of panels are as described in Fig. 2. Note the different ranges of $\%$ relative hybridization values between panels.

bridization signals could be detected from the DCM down to the bottom of the photic layer (see Fig. 4 and Fig. S2 in the Supplement).

The distribution of the main Prochlorococcus clades was previously analyzed in September 1999 during the PROSOPE cruise using the same molecular approach (Garczarek et al., 2007) and gave comparable results. Indeed, the HLI population dominated in the upper layer over the whole transect and HLII was negligible, except at Sta. 5 (located near BOUM Sta. 16; Fig. 1), where the HLII hybridization signal reached $8 \%$ at $25 \mathrm{~m}$, one fifth of the HLI signal. 

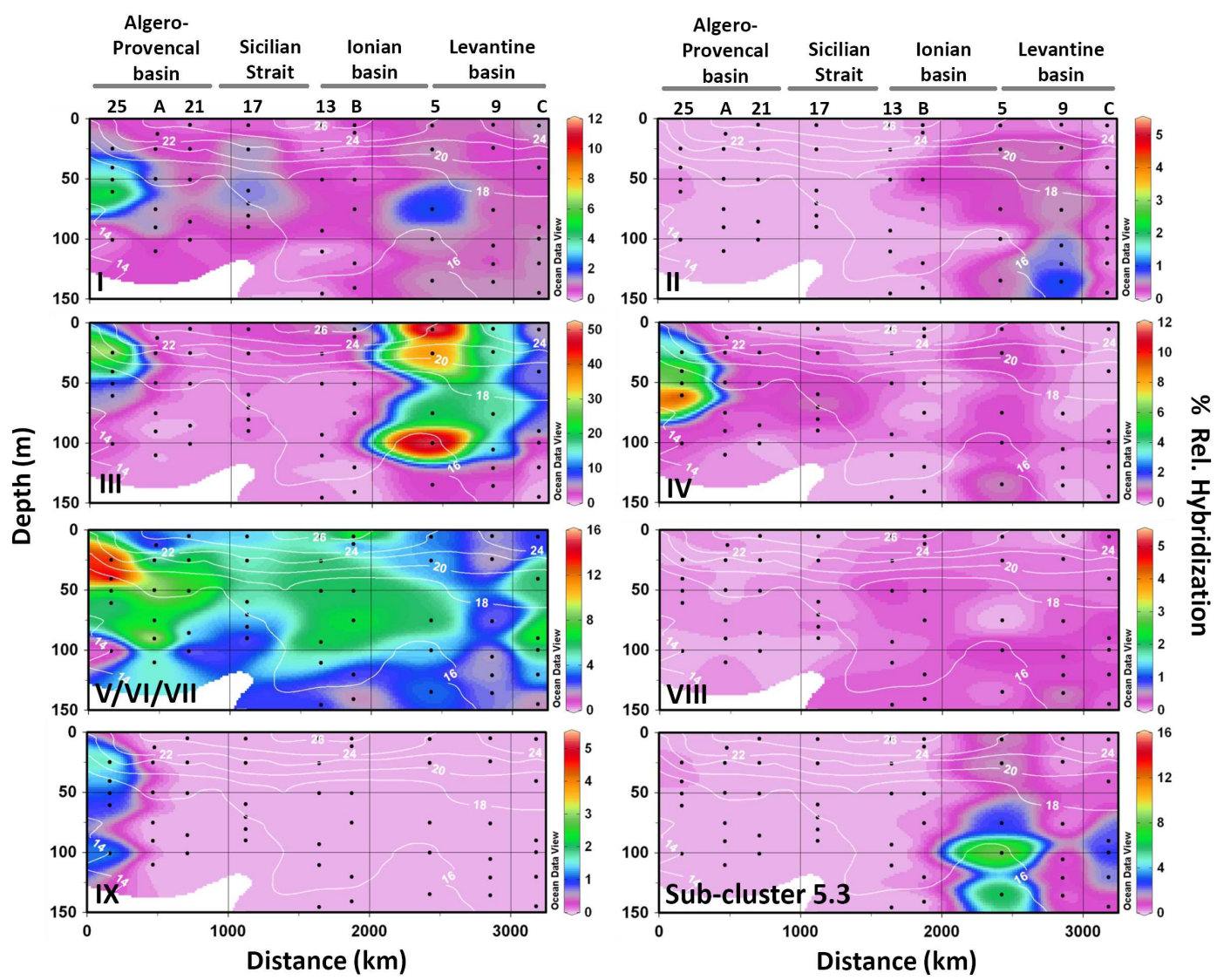

Fig. 5. Vertical distribution of different phylogenetic groups of Synechococcus along the BOUM cruise track, as analyzed by dot blot hybridization using 16S rRNA gene specific oligonucleotide probes targeting sub-cluster 5.1 clades I to IX and sub-cluster 5.3. See Table 1 for correspondence to sequenced strains. Details of panels are as described in Fig. 2. Note the different ranges of \% relative hybridization values between panels.

\subsubsection{Synechococcus}

The set of clade-specific oligonucleotide probes designed by Fuller et al. (2003), which targets the nine major marine Synechococcus clades of sub-cluster 5.1 (i.e. individual probes against clades I, II, III, IV, VIII and IX, and a single probe against clades V, VI and VII) as well as subcluster 5.3 (formerly sub-cluster 5.1 , clade X; see Dufresne et al., 2008), was used to study the distribution of these clades in the Mediterranean Sea at selected stations of the BOUM (Fig. 5) and PROSOPE cruises (Fig. 6), as well as at Sta. BOUSSOLE (See Fig. S1 in the Supplement).

Clade I was most abundant in the vicinity of the DCM at mesotrophic stations of the Gulf of Lions (i.e. Sta. 25 during BOUM, Sta. DYF during PROSOPE and the nearby Sta. BOUSSOLE during BOUSSOLE 88), and was therefore found in fairly cold waters $\left(<17^{\circ} \mathrm{C}\right)$. In the rest of the BOUM transect, clade I was sometimes found at low abundance at depth, generally within the deep Synechococcus maximum. Clade IV generally exhibited a similar distribution pattern to clade I. However, its relative abundance was significantly higher than clade I in the northern part of the Algero-Provencal basin (Sta. 25 and BOUSSOLE) and lower at all other stations of the BOUM cruise. Similarly during the PROSOPE cruise, clade IV was dominant over clade I at Sta. 1 (Straits of Gibraltar) and the reverse at Sta. 5, where a significant abundance maximum of clade I cells occurred at $60 \mathrm{~m}$ (Fig. 6).

Clade III was present in the upper mixed layer at all stations of the BOUM transect with its maximum signal observed in surface waters. It was the predominant Synechococcus clade at Sta. 25, 5 and 9 (Fig. 5) and the hybridization signal extended throughout the top $100 \mathrm{~m}$ of most of the Levantine basin. Similarly, during the PROSOPE cruise, clade III was also the dominant clade in surface waters (except in the Alboran Sea) and its relative abundance as well as vertical extension increased eastwards (Fig. 6).

The probe targeting clades V, VI and VII gave strong relative hybridization signals (up to $15.5 \%$ ) at all stations and all depths examined during both the PROSOPE and BOUM cruises. During the latter cruise, it was the dominant Synechococcus group at most depths from Sta. A to B, with a 

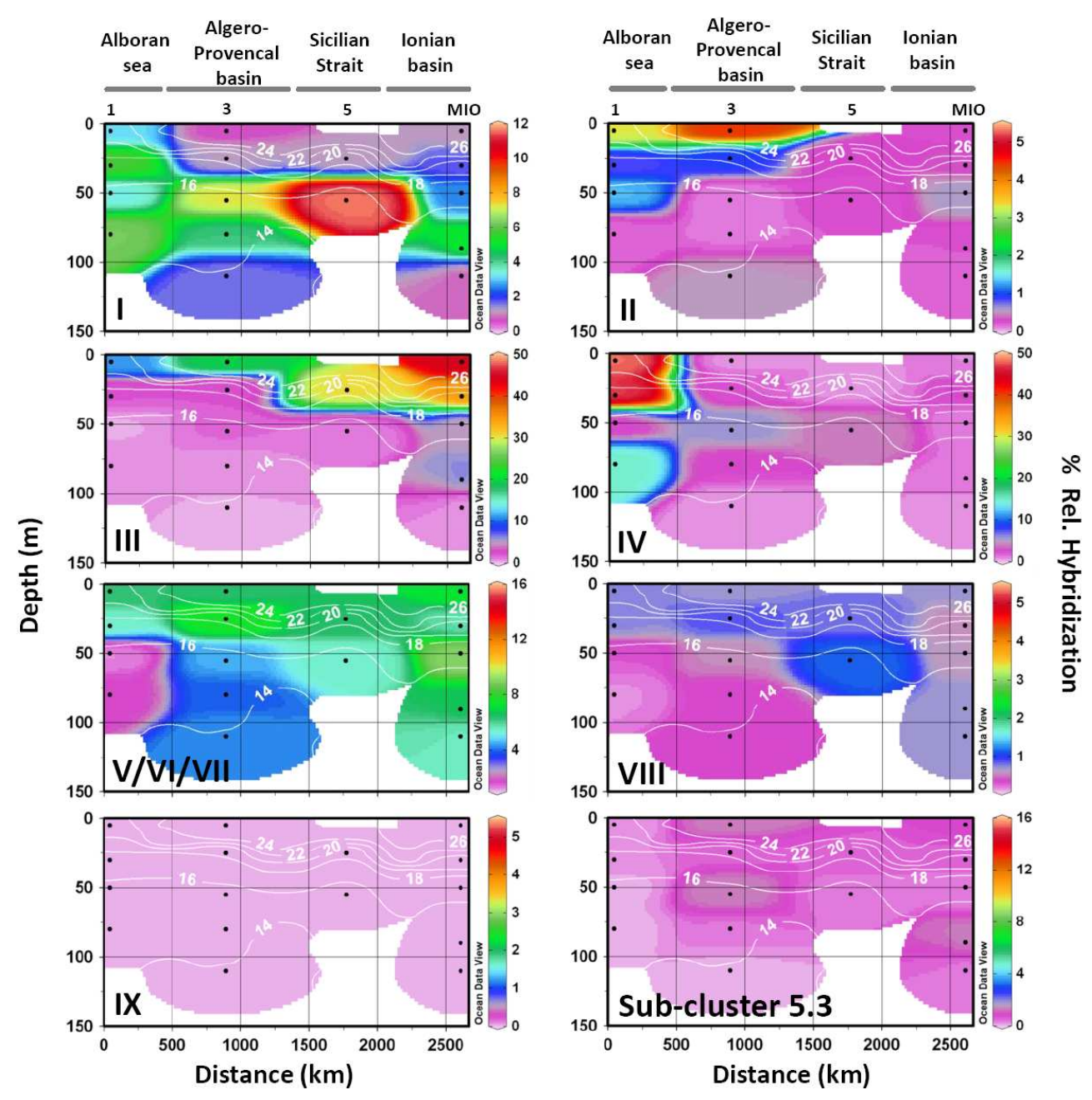

Fig. 6. Vertical distribution of different phylogenetic groups of Synechococcus along the W-E part of PROSOPE cruise track, as analyzed by dot blot hybridization using 16S rRNA gene specific oligonucleotide probes targeting sub-cluster 5.1 clades I to IX and sub-cluster 5.3. See Table 1 for correspondence to sequenced strains. For each panel, the $\mathrm{x}$ axis represents the cumulative distance in kilometers from a site $\mathrm{W}$ of Sta. $1\left(36.2^{\circ} \mathrm{N}-5.8^{\circ} \mathrm{W}\right)$ and the y axis represents depth in meters. Details of panels are as described in Fig. 2 . Note the different ranges of $\%$ relative hybridization values between panels.

maximum relative abundance found at the level of the Synechococcus density maximum.

The hybridization signals for clade II were never significant $(<1.0 \%$; Fig. 5) during the BOUM cruise. In contrast, during the PROSOPE cruise, low but significant clade II hybridization signals (up to $4.4 \%$ ) were observed in surface waters of the southwestern Mediterranean basin (Fig. 6), corresponding to a population that likely originated from the Atlantic Ocean. Clade VIII was virtually undetectable at all examined stations of both BOUM and PROSOPE cruises. Clade IX was detectable only at the mesotrophic Sta. 25 during BOUM at all sampled depths (Fig. 5, Table 2) and at Sta. BOUSSOLE (not shown) but not during PROSOPE. Finally, cells belonging to sub-cluster 5.3 were only detected in the Levantine basin during BOUM, with highest abundance in the DCM, i.e. below the Synechococcus density maximum.

\subsection{ITS clone libraries}

In order to explore in greater detail the genetic diversity of the Mediterranean Sea populations of picocyanobacteria, we sequenced clone libraries generated from the ITS region using general primers targeting both Prochlorococcus and Synechococcus (Rocap et al., 2002). Clone libraries were obtained from two selected depths at four stations of the BOUM cruise (A, B, 5 and C), as well as two depths of the BOUSSOLE site, sampled in mid-June 2009. In order to maximize the number of Synechococcus sequences in the data set, the two depths were chosen in the upper mixed layer and above the Prochlorococcus-dominated DCM (hereafter called "surface" and "mid-depth" samples, respectively). We sequenced 69-80 clones from each library and performed phylogenetic analyses using four methods (ML, Bayesian, 


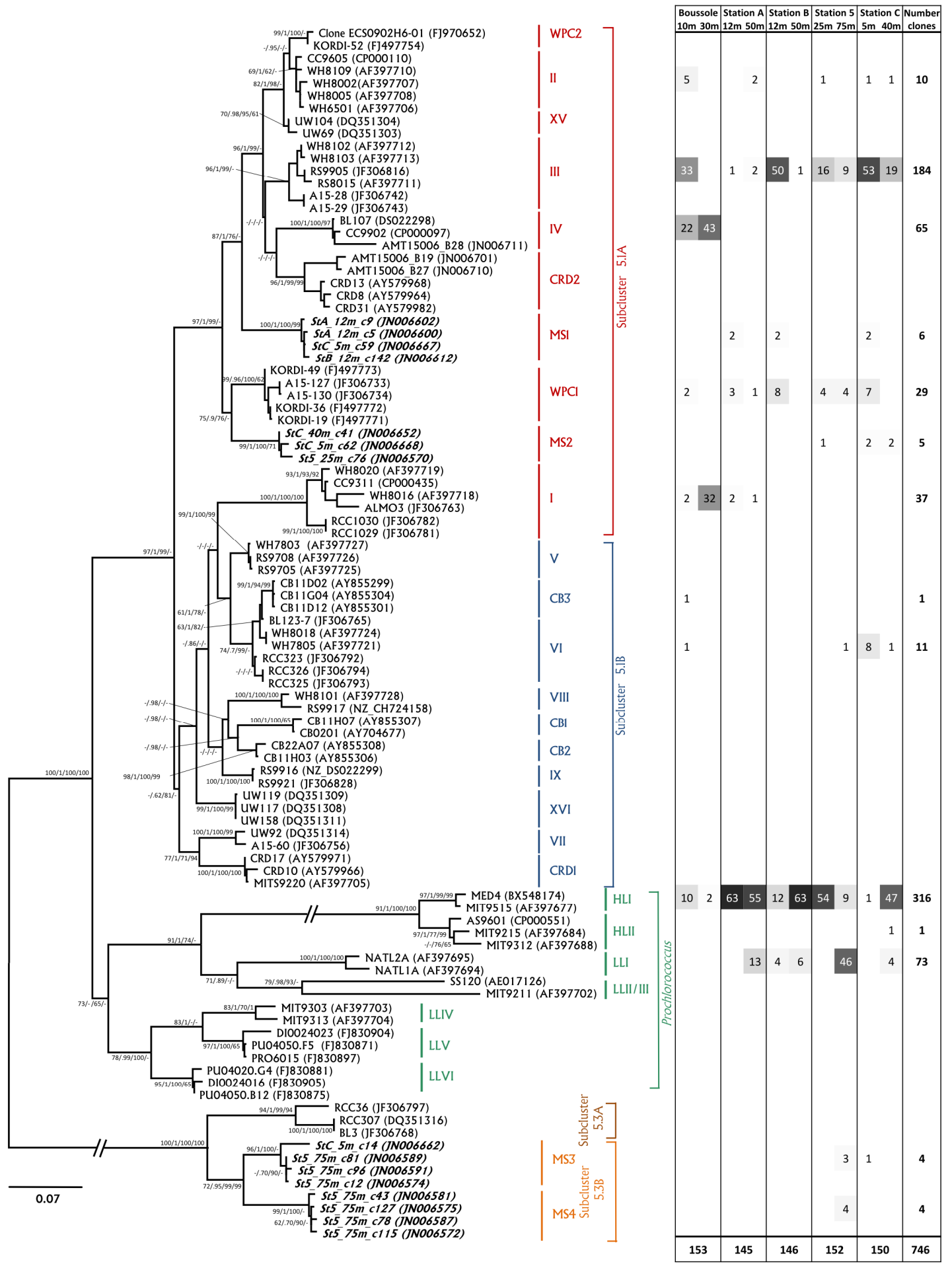

Fig. 7. Reference Maximum Likelihood (ML) tree of ITS sequences (based on a sequence alignment of 1135 positions, including tRNA) and table summarizing the number of clones of the different Synechococcus and Prochlorococcus clades/ecotypes for each clone library obtained from samples collected during the BOUM cruise. Novel environmental groups discovered during BOUM (MS1-4) were included in the reference tree and are shown in bold italics letters. The nomenclature used to name the BOUM samples is as follows: stX_Ym_cZ where $\times$ indicates the station number, Y, the sampling depth in meters and Z, the clone number. For sequence submission, the prefix "BOUM_" has been added in front of the sequence name. The clade/ecotype number or name as reported in the literature (Ahlgren and Rocap, 2006; Chen et al., 2006; Choi and Noh, 2009; Fuller et al., 2003; Dufresne et al., 2008) are indicated in colored letters for each group. Sequences belonging to the Synechococcus marine sub-cluster 5.3 were used as an outgroup. Numbers at nodes of the phylogenetic tree correspond to bootstrap values for ML analyses, posterior probability of Bayesian method (ranging between 0 and 1 ), and bootstrap values for Neighbor-Joining and Parsimony methods, respectively. Bootstraps, represented as a percentage, were obtained through 1,000 repetitions and only values higher than $60 \%$ are shown. The scale represents 0.07 substitutions per nucleotide. Branches corresponding to the Prochlororoccus HL ecotypes and Synechococcus marine sub-cluster 5.3 have been cut for readability (their full length is 0.36 and 0.5 substitutions per nucleotide, respectively). The table on the right indicates the number of sequences in clone libraries constructed for each station and depths; their vertical position in the table corresponds to their clade affiliation in the tree, as determined by Pplacer (see text). Numbers in the table are highlighted with increasing degree of shading. 
NJ and MP; Fig. 7). In only 2 out of 8 BOUM clone libraries (Sta. B at $12 \mathrm{~m}$ and Sta. C at $5 \mathrm{~m}$ ) as well as at both depths at Sta. BOUSSOLE, the proportion of sequences attributable to Synechococcus was higher than Prochlorococcus, and the large variability of this ratio (from 74:1 to 1:69) likely reflected the variable relative abundances of these two genera in the starting samples. Environmental sequences from each individual library were positioned using Pplacer v1.0 (see methods) in a reference tree containing 97 ITS sequences from strains or environmental samples representative of the whole ITS diversity reported so far in the Prochlorococcus and Synechococcus groups, including four new groups described below (see Fig. 7 and Fig. S2 in the Supplement, generated using Pplacer for each library).

Most sequences related to Prochlorococcus were assignable to the HLI clade, with the majority of sequences originating from "surface" samples at Sta. BOUSSOLE, A and 5 and from "mid-depth" samples at Sta. B and C. Prochlorococcus LLI were also present in abundance, but only in "mid-depth" samples, except at Sta. B where 4 sequences were obtained from the 'surface' sample (Fig. 7). There were no sequence attributable to either LLII, LLIII or LLIV in the whole data set but, as mentioned earlier, this result was expected since these ecotypes are abundant only near the bottom of the euphotic zone.

For Synechococcus, clade III was the dominant group at most stations except in the "mid-depth" sample from BOUSSOLE and in surface waters of Sta. A (Fig. 7 and Fig. S2 in the Supplement). In contrast, many clade I and IV sequences were retrieved from Sta. BOUSSOLE and a few clade I sequences from Sta. A, but no sequence from either clade from the three stations of the eastern Mediterranean basin. The next most abundant group of sequences belonged to the WPC1 clade, a lineage recently described based on culture isolates from the east China Sea and East Sea (Choi and Noh, 2009). This group was systematically present in surface waters at all sites and sometimes extended to middepth. All other Synechococcus clades contributed for less than 12 sequences and can therefore be considered as minor (at least for the dataset considered here). These included 10 sequences attributable to clade II, originating from various stations and depths, with half coming from surface waters of Sta. BOUSSOLE. Eight clade VI sequences were retrieved from surface waters at Sta. C, while single sequences of this clade and the closely related clade CB3 (previously only observed in Chesapeake Bay; Chen et al., 2006) were retrieved from $10 \mathrm{~m}$ at BOUSSOLE.

Interestingly, sequences from four new, uncultured Synechococcus clades, so-called MS1 through MS4, were observed in clone libraries (Fig. 7). MS1 was inferred to be phylogenetically located at the base of the group formed by clades II (which includes groups XV and WPC2), III, IV and CRD2 (Ahlgren and Rocap, 2006). It is noteworthy, however, that in trees made with full-length ITS sequences, MS1 in fact grouped with clade III, though with low bootstrap sup- port (see Fig. S2 in the Supplement). MS2 clustered with the above mentioned WPC1 clade using all phylogenetic methods except MP. The final two clades, MS3 and MS4, were related to one another and together formed a new group within sub-cluster 5.3. Given their phylogenetic position, supported by strong bootstrap values, and the relatively large distance between these two new clades and members of the initial subcluster 5.3, we propose to split the latter sub-cluster into two groups, so-called 5.3A and 5.3B (see Fig. 7).

MS1 was found both in the western and eastern basins (Sta. A, B and C) and comprised only "surface" sequences, whereas the three other uncultured clades were only retrieved in the eastern part of the transect, with the latter two mainly found in the Synechococcus abundance maximum.

\section{Discussion}

\subsection{Hydrology-driven variations in picocyanobacterial population structure}

Despite its relatively modest size, representing about $0.7 \%$ of the cumulative surface of marine areas, the Mediterranean Sea displays a large variety of hydrological conditions in summer, with a strong N-S gradient of SST (17$24^{\circ} \mathrm{C}$; Fig. 2a) and W-E gradient of salinity (37.4-39.6 PSU; Fig. 2b). Nutrient availability also varied tremendously along the BOUM transect, with a progressive N-S and W-E deepening of nutriclines, that was much steeper for the phosphocline than for the nitracline (Moutin et al., 2011; Pujo-Pay et al., 2011).

The spatial heterogeneity of hydrological conditions observed along the BOUM transect induced large variations in the vertical structure of both Prochlorococcus and Synechococcus populations, which seemed to respond differently to these physico-chemical changes. In the northern part of the Algero-Provencal basin, both genera formed subsurface abundance maxima and they either exhibited comparable cell densities (e.g. Sta. 27) or the latter genus outnumbered the former one (e.g. at Sta. 25 at all depths). This type of distribution is typical of mesotrophic areas (Partensky et al., 1996; Partensky et al., 1999). In the southern part of the Algero-Provencal basin, the Sicily Strait and the eastern Ionian Sea, Prochlorococcus was the dominant group at depth, while Synechococcus was most abundant in the upper mixed layer, with abundances usually above $10^{4}$ cells $\mathrm{ml}^{-1}$. However, because Prochlorococcus cells could not be precisely enumerated in the top $50 \mathrm{~m}$ or so (see methods), we cannot ascertain which of the two picocyanobacterial genera numerically dominated in this layer. This near surface Synechococcus abundance maximum is somewhat unusual compared to other oligotrophic areas with surface chlorophyll concentrations $<0.1 \mu \mathrm{g} \mathrm{Chl}{ }^{-1}$, such as the Atlantic ( $\mathrm{Li}$ et al., 1992; Olson et al., 1988; Olson et al., 1990; Zubkov et al., 2000) or Pacific gyres (Campbell et al., 1997; Grob 
et al., 2007), where Synechococcus are generally more homogeneously distributed in the upper 100-150 m layer and maximal cell densities are typically $2-5$ times lower. This raises the question of why do such high Synechococcus cell densities occur in surface waters of this nutrient-poor region of the Mediterranean Sea? Given the relatively close proximity of aerosol source emissions, which at the time of the BOUM cruise predominantly originated from the European continent (Ternon et al., 2011), it is possible that nutrient enrichment of surface waters by atmospheric dust deposition may have played a significant role in this phenomenon (Bonnet et al., 2005). Indeed, aerosols are enriched in inorganic nutrients $(\mathrm{Fe}, \mathrm{N}$ and $\mathrm{P}$, but with a $\mathrm{N}: \mathrm{P}$ ratio usually much higher than the Redfield ratio of 16:1; Paytan et al., 2009) and natural, nutrient-starved Synechococcus populations can respond quickly to such enrichment by rapid increases in cell concentrations (Hutchins et al., 2003; Mackey et al., 2009; Tanaka et al., 2011, Ternon et al., 2011).

Most stations between sites A and B exhibited a N:P ratio between 20 and 40 (integrated over the top $150 \mathrm{~m}$; see Crombet et al., 2011), indicating mild P-depletion in these waters. Oceanic strains of Synechococcus (e.g. WH8103 and WH8012) display a cellular N:P ratio in the same range (24-43), and therefore have a low $P$ requirement, which can even be further reduced by 3- or 4-fold when grown under $\mathrm{P}$ depletion (Bertilsson et al., 2003). Additionally, it was previously shown that Synechococcus populations from the Mediterranean Sea have a high affinity for orthophosphate and an elevated P uptake rate (Moutin et al., 2002). Thus, Synechococcus seems to be particularly well adapted to withstand the moderate $\mathrm{P}$ depletion occurring between Sta. A and B. Nevertheless, east of Sta. B, the intensity of P depletion seemingly increased since integrated $\mathrm{N}: \mathrm{P}$ ratios were between 50 to more than 100 at most stations (Crombet et al., 2011). This was confirmed by nutrient enrichment experiments using surface water, which showed that Synechococcus cells were clearly co-limited by both $\mathrm{N}$ and $\mathrm{P}$ at Sta. C, whilst they were only N-starved at Sta. A and B (even though, at the latter station, $\mathrm{N}+\mathrm{P}$ addition induced higher cell concentrations than $\mathrm{N}$ only; Tanaka et al., 2011).

This increased $\mathrm{P}$ depletion in eastern waters might explain in part the dramatic change in picocyanobacterial population structure observed between the Ionian sea and the Levantine basin. Indeed, in the easternmost region, we observed very low concentrations of both genera in the upper mixed layer (as indirectly indicated for Prochlorococcus by undetectable levels of its specific pigment divinyl-Chl $a$; Fig. 2f), and deep abundance maxima of both groups, located around $75 \mathrm{~m}$ for Synechococcus and $100 \mathrm{~m}$ for Prochlorococcus. These atypical vertical profiles might also be partially explained by factors other than macronutrient depletion, and in particular by copper toxicity, since the annual $\mathrm{Cu}$ deposition rate due to atmospheric aerosols is quite high in the eastern Mediterranean Sea (1-2 $\mathrm{mg} \mathrm{m}^{-2} \mathrm{yr}^{-1}$; Paytan et al., 2009). Indeed, Prochlorococcus growth was shown to be strongly affected by fairly low concentrations of this element, while Synechococcus cells can usually withstand higher concentrations (Mann et al., 2002). A more recent report claimed that some Cu-rich Saharan dust had a more severe toxic effect on the growth of Synechococcus in comparison to Prochlorococcus growing in the Red Sea (Paytan et al., 2009). It is therefore possible that, after events of dust deposition, abundances of both picocyanobacteria in the upper mixed layer of the eastern Mediterranean Sea may strongly vary over short time scales, in a direction depending on the nature and origin of aerosols.

The population structure of marine picocyanobacteria was globally comparable along common parts of the BOUM and PROSOPE cruises, despite the fact that sampling was held on different months and about a decade apart. It is worth noting though that in surface waters south of the Algero-Provencal basin and the Sicily Strait, Synechococcus abundances were two-fold lower during BOUM than during PROSOPE and the corresponding integrated cell concentrations were also 20-40\% lower (Table 2 and data not shown). Whether this results merely from seasonal differences or translates some more profound change in the degree of oligotrophy of the area still needs to be determined.

\subsection{Factors determining the distribution of picocyanobacterial ecotypes}

\subsubsection{Prochlorococcus}

A number of recent studies have shown that the phylogenetic composition of Prochlorococcus populations is tightly driven by environmental factors, primarily by light and secondarily by temperature. When the water column is stratified, there is a clear vertical partitioning of ecotypes, with HL (i.e. either HLI or HLII) occupying the upper layer, LLI an intermediate layer (generally the thermocline depth) and LLII-IV the base of the lit layer (Johnson et al., 2006; Zinser et al., 2006). Interestingly, this vertical partitioning has a genomic basis, since HL and LLI strains possess a number of adaptations to the deleterious effects of high irradiance and UV stress (including DNA repair genes, such as photolyases) that are absent in "strictly LL" ecotypes, i.e., LLII-IV (Kettler et al., 2007; Partensky and Garczarek, 2010; Rocap et al., 2003). In the present study, the LL-specific oligonucleotide probe used for dot blot hybridization analysis did not allow us to distinguish LLI (or eNATL) from LLIV (or eMIT9313) ecotypes, but the fact that ITS clone libraries from "mid-depth" (30 to $75 \mathrm{~m}$; see Fig. 7) contained many LLI and no "strictly LL" sequences clearly indicated that a vertical partitioning of ecotypes comparable to that previously observed in the Atlantic and Pacific Ocean (Johnson et al., 2006; Malmstrom et al., 2010) is also occurring in the Mediterranean Sea. Surprisingly, the LLII- (or eSS120-) specific probe detected significant levels of this ecotype only at the northwestern Mediterranean Sea stations (Sta. DYF during PROSOPE, 
Sta. 25 during BOUM and Sta. BOUSSOLE during BOUSSOLE 88). This suggests that the distribution of LLII in the Mediterranean Sea is restricted to temperate, mesotrophic areas. However, this clade was found to be abundant at depth at both long-term stations BATS (Bermuda Atlantic Time Series) and HOT (Hawaii Ocean Time series; Malmstrom et al., 2010) and its occurrence in such tropical and subtropical, oligotrophic waters somewhat contradicts this assumption. So it is probable that our LLII-specific probe in fact did not target exactly the same population as did the qPCR primers used by Malmstrom and coauthors.

The second most important factor determining Prochlorococcus ecotype distribution is temperature. Indeed, a clear latitudinal partitioning of HLI and HLII ecotypes was observed during two consecutive AMT transects through the Atlantic ocean in late summer/early fall (Johnson et al., 2006; Zwirglmaier et al., 2007). Although both HL clades co-occurred at low latitudes, HLII was always the dominant clade from $28^{\circ} \mathrm{S}$ to $33^{\circ} \mathrm{N}$; then, the ratio was progressively reversed at higher latitude, so that HLI became dominant above $32^{\circ} \mathrm{S}$ or $38^{\circ} \mathrm{N}$. If one extrapolates the HLI and HLII concentrations reported in the N Atlantic by Johnson et al. (2006) to the latitudinal range covered by the BOUM and PROSOPE transects in the Mediterranean Sea (33.6$43.2^{\circ} \mathrm{N}$ ), one should have expected to find the HLI:HLII abundance ratio ranging roughly from 1:1 in the Ionian and Levantine basins to 2000:1 at the northernmost Sta. 27. However, the HLII hybridization signal was most often lower than $1 \%$ of the EUB signal, except in subsurface waters at PROSOPE Sta. 5 (see Fig. 3 in Garczarek et al., 2007). This low abundance of the HLII ecotype in the Mediterranean Sea was independently confirmed by the occurrence of only one HLII sequence (at Sta. C) in our ITS clone libraries compared to 316 HLI sequences.

The scarcity of the HLII ecotype in the southern part of the Mediterranean Sea, in particular in the Levantine basin, is somewhat puzzling. Indeed, the growth temperature range of strains representative of this ecotype (MIT9312 and MIT9215) is $16-30^{\circ} \mathrm{C}$, with growth optima between 23 and $28^{\circ} \mathrm{C}$. In contrast, HLI strains (MED4 and MIT9515) can grow in the $11-28^{\circ} \mathrm{C}$ range, with growth optima between 22 and $26^{\circ} \mathrm{C}$ (Johnson et al., 2006; Zinser et al., 2007). In field populations, temperature vs. abundance curves differ even more dramatically between the two HL ecotypes: HLII abundance increases steadily with temperature from less than $10^{2}$ cells ml ${ }^{-1}$ at $14^{\circ} \mathrm{C}$ up to a plateau of $1-4 \times$ $10^{5}$ cells ml ${ }^{-1}$ at $25-28^{\circ} \mathrm{C}$, whereas HLI abundance is already high (ca. $10^{3}$ cells ml-1) at $14^{\circ} \mathrm{C}$, peaks around $19^{\circ} \mathrm{C}$ then declines drastically above $25^{\circ} \mathrm{C}$ (Zinser et al., 2007).

The average SST over the 1999-2008 period for the coldest and warmest months (i.e. March and August, respectively) were $14.5-25.8^{\circ} \mathrm{C}, 16.6-27.6^{\circ} \mathrm{C}$ and $17.3-28.0^{\circ} \mathrm{C}$ for Sta. A, B and C, respectively (Fig. 2a-c). Although the wintertime SST at Sta. A was close to the lower limit of the HLII growth temperature range, suggesting that this ecotype might not be able to survive year-round in these waters, the SST range recorded at Sta. B and C were completely compatible with its growth temperature range. Furthermore, the Mediterranean Sea is connected to the Red Sea via the Suez Canal and it was shown that the dominant Prochlorococcus ecotype year-round in the Gulf of Aqaba is HLII (Fuller et al., 2005), constituting a possible reservoir of HLII cells for the southeastern Mediterranean Sea. It is even possible that coastal waters of the Levantine basin might display a higher HLII to HLI ecotype ratio than offshore waters, as suggested by a recent analysis of a microbial community metagenome collected in surface waters near Israeli coasts (Feingersch et al., 2010).

Thus, to explain the scarcity of HLII cells in open Levantine surface waters in summer, despite seemingly optimal temperatures for growth, we hypothesize that, in this area, the upper mixed layer exhibits a combination of features that make these waters unfavorable to growth of Prochlorococcus HL populations in general, as attested by undetectable divinyl-Chl $a$ concentrations (see Fig. 2). These features likely include extremely low macronutrient concentrations, triggering $\mathrm{N}$ and $\mathrm{P}$ co-limitation of growth, and/or high and potentially toxic levels of copper (Mann et al., 2002; Paytan et al., 2009), though some other yet-to-be identified factors may also be involved. We further assume that local HLI populations are able to survive at low cell concentrations under these stress conditions, whereas alien HLII populations entering the Mediterranean Sea via the Suez Canal cannot, and are rapidly outcompeted and eliminated. It would be interesting to determine whether conditions may become more favorable in the Levantine basin at another time of the year by following the abundance of Prochlorococcus populations on a monthly scale, since such time series performed at the long-term Sta. HOT (off Hawaii) and BATS (off Bermuda) revealed strong seasonal variations of the relative abundance of the different ecotypes, with distinct annual patterns for each ecotype (Malmstrom et al., 2010).

\subsubsection{Synechococcus}

Whilst for Prochlorococcus the same phylogenetic groups were found at comparable relative depths from one end of the Mediterranean Sea to the other (Fig. 4; see also Garczarek et al., 2007), we observed large variations in the genetic diversity of Synechococcus populations both vertically and horizontally along the BOUM and PROSOPE cruise transects (Figs. 5 and 6). It must be noted that the two molecular approaches used here to assess genetic diversity within this genus provided slightly different pictures of the Synechococcus community structure. For instance, dot blot hybridization seemingly indicated that the two most abundant Synechococcus groups in the Mediterranean Sea were clade III and the phylogenetic cluster formed by the closely related clades V/VI/VII. It is worth noting though, that the clade V/VI/VII probe also recognizes Synechococcus 
strain MITS9220, which is phylogenetically affiliated to the CRD1 clade (Fig. 7). While the predominance of clade III was confirmed by clone library sequencing, since the majority of Synechococcus ITS sequences belonged to this clade, there were fewer sequences attributable to clades V, VI (and the closely related group CB3), VII and/or CRD1 than would have been expected from hybridization results (Fig. 7). Moreover, there is a single mismatch between this probe and sequences of the recently described clade WPC1 (Choi and Noh, 2009), which appears to be widely distributed in the Mediterranean Sea (Fig. 7). It is therefore possible that the clade V/VI/VII probe can also recognize this particular group. In any case, cells targeted by this probe were found everywhere in the Mediterranean Sea, with highest abundances (up to $15.5 \%$ relative hybridization) in the nutrientrich waters of the northern Algero-Provencal basin (Figs. 5 and 6). This is consistent with previous literature on other regions of the ocean, since this group was observed throughout the AMT transect in the Atlantic Ocean, with the highest concentrations in temperate waters of the southern and northern hemispheres (e.g., up to $28 \%$ relative hybridization off Cape Town) and in upwelling waters of the northern Arabian Sea (up to $53 \%$ relative hybridization; Zwirglmaier et al., 2007, 2008).

Clade III was most abundant in the surface layer at all stations of the western basin and the Ionian Sea (Fig. 5). This result was confirmed by the much larger number of clade III sequences obtained in clone libraries from "surface" than "middepth" (except at Sta. A, where only three sequences were retrieved at this station). This is consistent with earlier studies which showed that clade III was preferentially found in the upper mixed layer (Toledo et al., 1999; Toledo and Palenik, 2003). However, in the Levantine basin, its depth distribution extended to the whole euphotic layer and this seems to be directly related to the deepening of the Synechococcus density maximum in this area (Fig. 2e). Zwirglmaier et al. (2008) previously suggested that clade III was an "oligotrophic" clade, since they observed that members of this clade were confined to a fairly narrow window of nitrate and phosphate concentration, even though they displayed no obvious latitudinal preference. Genomic analysis of the clade III isolate Synechococcus sp. WH8102, indeed shows that it contains a large number of nutrient transporters but a reduced regulatory machinery (Dufresne et al., 2008; Palenik et al., 2003; Scanlan et al., 2009), strengthening the idea that members of this clade are well adapted to stable, low-nutrient environments. Moreover, this strain exhibits a well-developed cellular response to P-stress that includes the expression of genes encoding high-affinity periplasmic P-binding proteins and at least three organic phosphatases that could provide a competitive advantage for scavenging $\mathrm{P}$ from alternative sources when inorganic P is scarce (Ostrowski et al., 2010; Tetu et al., 2009).
Clades I and IV were both most abundant in mesotrophic waters of the Mediterranean Sea (though with higher signals for clade IV at all depths), suggesting that both clades are adapted to high-nutrient/low-temperature waters. Faint hybridization signals were also observed in the southern Mediterranean Sea, with maximal values for both clades often occurring at the deep Synechococcus maximum, which was generally found below the $18^{\circ} \mathrm{C}$ isoline (Fig. 2), confirming the preference of these clades for cool waters. The co-occurrence of Synechococcus clades I and IV has been well documented in the Atlantic and Pacific Oceans, where they constitute the dominant Synechococcus groups at latitudes above $30^{\circ} \mathrm{N} / \mathrm{S}$ (Brown and Fuhrman, 2005; Zwirglmaier et al., 2007; Zwirglmaier et al., 2008; Tai et al., 2011; Tai and Palenik, 2009). Nevertheless, the ratio of abundances of the two clades may vary both spatially and temporally. Indeed, it was observed at a coastal site off South California that these clades displayed different seasonal cycles (Tai and Palenik, 2009). Whilst clade IV was the dominant type over most of the year, clade I outnumbered clade IV just before the annual abundance peak of Synechococcus cell density. Genome sequences of one clade I strain (CC9311) and two clade IV strains (CC9902 and BL107) have been obtained so far (Dufresne et al., 2008; Palenik et al., 2006; Scanlan et al., 2009). The former has a slightly larger genome than the latter, and encodes a larger set of proteins involved in signal sensing (such as histidine kinases and response regulators) and metal binding (including multiple genome encoded copies of ferritin and Zn-binding metallothioneins). Thus, clade I might have been expected to be better adapted to the variability experienced by coastal/mesotrophic environments than its clade IV counterpart, which somewhat contradicts the higher relative abundance of clade IV over clade I in nutrient-rich areas (Tai and Palenik, 2009; this study). Hence, understanding the factors that allow the cooccurrence of clades I and IV, but also the dominance of one clade over the other still awaits extensive comparisons of genomes from many more strains of both clades and/or refined comparative physiological studies in culture (including co-cultures).

The presence of sub-cluster 5.3 at depth in the Levantine basin during BOUM, with the highest abundance observed at Sta. 5, is consistent with ITS sequencing, since seven sequences of this group were retrieved at this station from the $75 \mathrm{~m}$ sample. Previously, this group (ex sub-cluster 5.1, clade X) had only been reported from subsurface samples in warm, coastal waters of the Arabian Sea, i.e., in a fairly different niche (Fuller et al., 2003; Fuller et al., 2006). Yet, we showed here that this sub-cluster is more diverse than previously thought and thus it is not unexpected that, like for sub-cluster 5.1 (Dufresne et al., 2008; Scanlan et al., 2009), different clades within this group might be adapted to different habitats. 
Both dot blot hybridization and clone library sequencing suggest that clades II, VIII and IX are only minor components of the Synechococcus community in the Mediterranean Sea. So far, all characterized clade VIII strains, including a number isolated from the Gulf of Aqaba (Fuller et al., 2003; Fuller et al., 2006), are phycocyanin-containing halotolerant isolates, and this may explain why members of this clade have never been found in significant numbers in open ocean samples (Zwirglmaier et al., 2008). Clade IX has only been found at low levels in warm and coastal sub-surface waters of the northern Arabian Sea (Fuller et al., 2006) and was undetectable elsewhere, so its preferred niche remains unclear. The low abundance of clade II in the Mediterranean Sea, suggested by dot blot hybridization and confirmed by the occurrence of few ITS sequences in clone libraries, is somewhat more surprising. In the California Current (Toledo and Palenik, 2003), the Red Sea (Fuller et al., 2003), the northern part of the Arabian Sea (Fuller et al., 2006) and the region of the Morocco upwelling (Zwirglmaier et al., 2007), this clade constituted a large proportion of the Synechococcus population (up to $75 \%$ relative hybridization) in surface waters in tropical and subtropical areas. Indeed, Zwirglmaier et al. (2008) showed that this clade was particularly well represented in warm waters, ranging from $22^{\circ} \mathrm{C}$ to $28^{\circ} \mathrm{C}$, while other clades either possess a larger temperature tolerance $\left(7-28^{\circ} \mathrm{C}\right.$ for clades III and V/VI/VII) or are restricted to cooler waters $\left(7-18^{\circ} \mathrm{C}\right.$ for clades I and IV). Thus, one might have expected to find notable abundances of clade II in the Mediterranean Sea, at least at the easternmost Sta. C, where SST reaches $27^{\circ} \mathrm{C}$ in summer (Fig. 2a). Like for Prochlorococcus HLII, some environmental factors other than temperature possibly inhibit the proliferation of this clade, at least during the warmest months of the year.

\section{Conclusions}

A number of recent studies suggest that a global increase in the temperature of the Mediterranean Sea has occurred in the last few decades (Saaroni et al., 2003 and references therein) and that this oceanic region is particularly vulnerable to global change (see e.g., Belkin, 2009). However, the intensity of this rise may vary locally, as shown here by differences in multi-annual trends in summer SST anomalies over the 1985-2010 period, in the vicinity of the three long-term stations of the BOUM cruise, located in the center of distinct anticyclonic eddies. Interestingly, the increasing trend was only significant in the eastern Mediterranean Sea and reached $0.5^{\circ} \mathrm{C}$ per decade in the Levantine basin. This is consistent with climate models, which forecast that by the end of the 21st century the Mediterranean Sea SST's will be, on average, 3 to $4{ }^{\circ} \mathrm{C}$ warmer than today (Coll et al., 2010; Hertig and Jacobeit, 2008; Somot et al., 2006). Even if these multi-annual SST variations may seem relatively modest compared to seasonal SST variations (Fig. 3), this change could potentially induce drastic changes in the composition of marine microbial communities (including picocyanobacteria) at mid (decades) or long term (centuries). Indeed, a rise in the annual temperature range by only a few degrees should theoretically favor subtropical groups over local populations, leading to their progressive replacement.

Here, we studied the genetic diversity and distribution of Prochlorococcus and Synechococcus clades/ecotypes during the PROSOPE and BOUM cruises held almost a decade apart, using two different and complementary molecular approaches. For Prochlorococcus, there was a large phylogenetic diversity down the water column at any given site but the same ecotypes were found from one end of the Mediterranean Sea to the other. The dominant clade in the upper mixed layer was HLI during both cruises. Thus, even though the Mediterranean Sea is located in the boundary zone between the distribution areas of HLI and HLII ecotypes and we have evidence that HLII is present in this area, changes that have occurred in the hydrology of the Mediterranean Sea as a result of global warming, have not been sufficient yet to provoke a significant change in the dominant HL population, even though the annual SST range in the Levantine basin is seemingly suitable for HLII growth. The Eastern Mediterranean Sea is known to have a number of unique hydrological features compared to other oligotrophic areas, and our results suggest that environmental factors other than temperature (and light, if one considers the LL ecotypes) must be taken into account to reliably predict any future changes in the relative abundances of Prochlorococcus ecotypes.

For Synechococcus, analyses of the distribution of the different clades reported here for the Mediterranean Sea strengthened generalizations made by previous studies in other parts of the world ocean, including the fact that clades I, III and IV are locally the most abundant groups, with clades I and IV co-occurring and being restricted to cool waters, while clade III is ubiquitously found in oligotrophic areas (Bouman et al., 2006; Johnson et al., 2006; Zwirglmaier et al., 2007; Zwirglmaier et al., 2008). However, our study also revealed the presence in the Mediterranean Sea of novel groups (MS1, MS2 and sub-cluster 5.3B) and the large relative abundance of cells detected by the probe targeting clades V/VI/VII/CRD1. These data clearly point to a need for the design of further probes, or the use of alternate approaches, such as quantitative PCR (Tai and Palenik, 2009), hybridization to liquid bead-arrays (Tai et al., 2011) or high throughput sequencing using a recently developed functional gene marker (petB) with high taxonomic resolution (Mazard et al., 2011), which allow precise mapping of the distribution of individual clades or genotypes in the environment. 
Our study advocates the interest of bioindicators (such as Prochlorococcus HLII or the Synechococcus clade II) to complement the classical physico-chemical parameters usually measured to monitor the impact of global changes on marine ecosystems. It also points out the need for time series analyses of the microbial diversity in the Mediterranean Sea, especially in the Levantine basin, which is seemingly the most affected by global warming and which exhibits a number of atypical hydrological traits for an oligotrophic area. Such studies would not only show whether the different taxonomic groups display different annual patterns of abundance (Malmstrom et al., 2010; Tai and Palenik, 2009), but also help unveil what factors, besides temperature, control the composition of these microbial communities.

\section{Supplementary material related to this article is available online at: http://www.biogeosciences.net/8/2785/2011/ bg-8-2785-2011-supplement.pdf.}

Acknowledgements. This work was supported by the French ANR program PELICAN (PCS-09-GENM-200) and the PROSOPE and BOUM projects of the LEFE-CYBER program. DMF was supported by the National Commission of Scientific and Technological Investigation of Chile (CONICYT), SM was in receipt of a Natural Environment Research Council (NERC) PhD studentship and MO was supported by NERC grant NE/F004249/1 awarded to DJS. FM and EMB were respectively supported by the European programmes ERA-net BiodivERsA (BioMarKs project) and EPOCA (grant 211384). We thank Thierry Moutin for providing us access to BOUM cruise data and to several manuscripts prior to publication. The captains and crews are kindly acknowledged for their help during the PROSOPE, BOUM (both on board the $\mathrm{R} / \mathrm{V}$ L'Atalante) and BOUSSOLE 88 cruises (on board the R/V Tethys II). Emilie Diamond is warmly thanked for her help during the BOUSSOLE88 cruise as well as Claudie Marec, Louis Prieur and Marc Picheral for CTD operations during BOUM. We are also grateful to Nyree West for generating dot blots from the DYF site of PROSOPE, Morgan Perennou and Delphine Naquin for their help with ITS sequencing and data treatment and Vincent Moron and Dominique Davoult for helpful discussions on temperature data analysis.

Edited by: T. Moutin

\section{References}

Ahlgren, N. A. and Rocap, G.: Culture isolation and cultureindependent clone libraries reveal new marine Synechococcus ecotypes with distinctive light and $\mathrm{N}$ physiologies, Appl. Environ. Microbiol., 72, 7193-7204, 2006.

Amann, R. I., Krumholz, L., and Stahl, D. A.: Fluorescentoligonucleotide probing of whole cells for determinative, phylogenetic and environmental studies in microbiology, J. Bacteriol., $172,762-770,1990$.
Belkin, I. M.: Rapid warming of large marine ecosystems, Prog. Oceanogr., 81, 207-213, 2009.

Bertilsson, S., Berglund, O., Karl, D. M., and Chisholm, S. W.: Elemental composition of marine Prochlorococcus and Synechococcus: Implications for the ecological stoichiometry of the sea, Limnol. Oceanogr., 48, 1721-1731, 2003.

Bianchi, C. N.: Biodiversity issues for the forthcoming tropical Mediterranean Sea, Hydrobiologia, 580, 7-21, 2007.

Bonnet, S., Guieu, C., Chiaverini, J., Ras, J., and Stock, A.: Impact of atmospheric inputs on the autotrophic communities in a low nutrient low chlorophyll system, Limnol. Oceanogr., 50, 1810 1819, 2005.

Bouman, H. A., Ulloa, O., Scanlan, D. J., Zwirglmaier, K., Li, W. K., Platt, T., Stuart, V., Barlow, R., Leth, O., Clementson, L., Lutz, V., Fukasawa, M., Watanabe, S., and Sathyendranath, S.: Oceanographic basis of the global surface distribution of Prochlorococcus ecotypes, Science, 312, 918-921, 2006.

Brown, M. V. and Fuhrman, J. A.: Marine bacterial microdiversity as revealed by internal transcribed spacer analysis, Aquat. Microb. Ecol., 41, 15-23, 2005.

Campbell, L., Nolla, H. A., and Vaulot, D.: The importance of Prochlorococcus to community structure in the central North Pacific Ocean, Limnol. Oceanogr., 39, 954-961, 1994.

Campbell, L., Liu, H. B., Nolla, H. A., and Vaulot, D.: Annual variability of phytoplankton and bacteria in the subtropical North Pacific Ocean at Station ALOHA during the 1991-1994 ENSO event, Deep Sea Res. Pt. I, 44, 167-192, 1997.

Chen, F., Wang, K., Kan, J., Suzuki, M. T., and Wommack, K. E.: Diverse and unique picocyanobacteria in Chesapeake Bay, revealed by $16 \mathrm{~S}-23 \mathrm{~S}$ rRNA internal transcribed spacer sequences, Appl. Environ. Microbiol., 72, 2239-2243, 2006.

Choi, D. H. and Noh, J. H.: Phylogenetic diversity of Synechococcus strains isolated from the East China Sea and the East Sea FEMS Microbiol. Ecol., 69, 439-448, 2009.

Coleman, M. L. and Chisholm, S. W.: Code and context: Prochlorococcus as a model for cross-scale biology, Trends Microbiol., 15, 399-407, 2007.

Coll, M., Piroddi, C., Steenbeek, J., Kaschner, K., Ben Rais Lasram, F., Aguzzi, J., Ballesteros, E., Bianchi, C. N., Corbera, J., Dailianis, T., Danovaro, R., Estrada, M., Froglia, C., Galil, B. S., Gasol, J. M., Gertwagen, R., Gil, J., Guilhaumon, F., Kesner-Reyes, K., Kitsos, M. S., Koukouras, A., Lampadariou, N., Laxamana, E., Lopez-Fe de la Cuadra, C. M., Lotze, H. K., Martin, D., Mouillot, D., Oro, D., Raicevich, S., Rius-Barile, J., Saiz-Salinas, J. I., San Vicente, C., Somot, S., Templado, J., Turon, X., Vafidis, D., Villanueva, R., and Voultsiadou, E.: The biodiversity of the Mediterranean Sea: estimates, patterns, and threats, PLoS One, 5, e11842, 2010.

Crombet, Y., Leblanc, K., Quéguiner, B., Moutin, T., Rimmelin, P., Ras, J., Claustre, H., Leblond, N., Oriol, L., and Pujo-Pay, M.: Deep silicon maxima in the stratified oligotrophic Mediterranean Sea, Biogeosciences, 8, 459-475, doi:10.5194/bg-8-4592011, 2011.

D'Ortenzio, F. and Ribera d'Alcalà, M.: On the trophic regimes of the Mediterranean Sea: a satellite analysis, Biogeosciences, 6, 139-148, doi:10.5194/bg-6-139-2009, 2009.

Dufresne, A., Ostrowski, M., Scanlan, D. J., Garczarek, L., Mazard, S., Palenik, B. P., Paulsen, I. T., Tandeau de Marsac, N., Wincker, P., Dossat, C., Ferriera, S., Johnson, J., Post, A. F., Hess, W. R., 
and Partensky, F.: Unraveling the genomic mosaic of a ubiquitous genus of marine cyanobacteria, Genome Biol., 9, R90, 2008.

DuRand, M. D., Olson, R. J., and Chisholm, S. W.: Phytoplankton population dynamics at the Bermuda Atlantic Time-series station in the Sargasso Sea, Deep Sea Res. Pt. II, 48, 1983-2003, 2001.

Eguchi, M., Ostrowski, M., Fegatella, F., Bowman, J., Nichols, D., Nishino, T., and Cavicchioli, R.: Sphingomonas alaskensis strain AFO1, an abundant oligotrophic ultramicrobacterium from the North Pacific, Appl. Environ. Microbiol., 67, 4945-4954, 2001.

Feingersch, R., Suzuki, M. T., Shmoish, M., Sharon, I., Sabehi, G., Partensky, F., and Béjà, O.: Microbial community genomics in eastern Mediterranean Sea surface waters, ISME J., 4, 78-87, 2010

Felsenstein, J.: PHYLIP - Phylogeny inference package (version 3.2), Cladistics, 5, 164-166, 1989.

Fuller, N. J., Marie, D., Partensky, F., Vaulot, D., Post, A. F., and Scanlan, D. J.: Clade-specific 16 S ribosomal DNA oligonucleotides reveal the predominance of a single marine Synechococcus clade throughout a stratified water column in the Red Sea, Appl. Environ. Microbiol., 69, 2430-2443, 2003.

Fuller, N. J., West, N. J., Marie, D., Yallop, M., Rivlin, T., Post, A. F., and Scanlan, D. J.: Dynamics of community structure and phosphate status of picocyanobacterial populations in the Gulf of Aqaba, Red Sea, Limnol. Oceanogr., 50, 363-375, 2005.

Fuller, N. J., Tarran, G. A., Yallop, M., Orcutt, K. M., and Scanlan, D. J.: Molecular analysis of picocyanobacterial community structure along an Arabian Sea transect reveals distinct spatial separation of lineages, Limnol. Oceanogr., 51, 2515-2526, 2006.

Garczarek, L., Dufresne, A., Rousvoal, S., West, N. J., Mazard, S., Marie, D., Claustre, H., Raimbault, P., Post, A. F., Scanlan, D. J., and Partensky, F.: High vertical and low horizontal diversity of Prochlorococcus ecotypes in the Mediterranean Sea in summer, FEMS Microbiol. Ecol., 60, 189-206, 2007.

Goericke, R. and Welschmeyer, N. A.: The marine prochlorophyte Prochlorococcus contributes significantly to phytoplankton biomass and primary production in the Sargasso Sea, Deep Sea Res. Pt. I, 40, 2283-2294, 1993.

Grob, C., Ulloa, O., Li, W. K. W., Alarcon, G., Fukasawa, M., and Watanabe, S.: Picoplankton abundance and biomass across the eastern South Pacific Ocean along latitude 32.5 degrees S, Mar. Ecol. Progr. Ser., 332, 53-62, 2007.

Guindon, S. and Gascuel, O.: A simple, fast, and accurate algorithm to estimate large phylogenies by maximum likelihood, System Biol., 52, 696-704, 2003.

Hall, T. A.: BioEdit: a user-friendly biological sequence alignment editor and analysis program for Windows 95/98/NT, Nucl. Acids Symp. Ser., 41, 95-98, 1999.

Hertig, E. and Jacobeit, J.: Downscaling future climate change: Temperature scenarios for the Mediterranean area, Global Planet. Change, 63, 127-131, 2008.

Huelsenbeck, J. P. and Ronquist, F.: MRBAYES: Bayesian inference of phylogenetic trees, Bioinformatics, 17, 754-755, 2001.

Hutchins, D. A., Pustizzi, F., Hare, C. E., and DiTullio, G. R.: A shipboard natural community continuous culture system for ecologically relevant low-level nutrient enrichment experiments, Limnol Oceanogr. Meth., 1, 82-91, 2003.

Johnson, Z. I., Zinser, E. R., Coe, A., McNulty, N. P., Woodward, E. M., and Chisholm, S. W.: Niche partitioning among Prochlorococcus ecotypes along ocean-scale environmental gradients, Sci- ence, 311, 1737-1740, 2006.

Katoh, K. and Toh, H.: Improved accuracy of multiple ncRNA alignment by incorporating structural information into a MAFFT-based framework, BMC Bioinfo., 9, 212, 2008.

Kettler, G., Martiny, A. C., Huang, K., Zucker, J., Coleman, M. L., Rodrigue, S., Chen, F., Lapidus, A., Ferriera, S., Johnson, J., Steglich, C., Church, G., Richardson, P., and Chisholm, S. W.: Patterns and implications of gene gain and loss in the evolution of Prochlorococcus, PLoS Genet., 3, e231, 2007.

Lavin, P., González, B., Santibáñez, J., Scanlan, D., and Ulloa, O.: Novel lineages of Prochlorococcus dominate the picocyanobacterial community within the oxygen minimum zone of the eastern tropical South Pacific, Environ. Microbiol. Rep., 2, 728-738, 2010.

Lejeusne, C., Chevaldonné, P., Pergent-Martini, C., Boudouresque, C. F., and Pérez, T.: Climate change effects on a miniature ocean: the highly diverse, highly impacted Mediterranean Sea, Trends Ecol. Evol., 25, 250-260, 2009.

Li, W. K. W., Dickie, P. M., Irwin, B. D., and Wood, A. M.: Biomass of bacteria, cyanobacteria, prochlorophytes and photosynthetic eukaryotes in the Sargasso Sea, Deep Sea Res. Pt. I, 39, 501519, 1992.

Li, W. K. W.: Primary productivity of prochlorophytes, cyanobacteria, and eukaryotic ultraphytoplankton: measurements from flow cytometric sorting, Limnol. Oceanogr., 39, 169-175, 1994.

Li, W. Z. and Godzik, A.: Cd-hit: a fast program for clustering and comparing large sets of protein or nucleotide sequences, Bioinformatics 22, 1658-1659, 2006

Lindell, D. and Post, A. F.: Ultraphytoplankton succession is triggered by deep winter mixing in the Gulf of Aqaba (Eilat), Red Sea, Limnol. Oceanogr., 40, 1130-1141, 1995.

Mackey, K. R. M., Rivlin, T., Grossman, A. R., Post, A. F., and Paytan, A.: Picophytoplankton responses to changing nutrient and light regimes during a bloom, Mar. Biol., 156, 1531-1546, 2009.

Malmstrom, R. R., Coe, A., Kettler, G. C., Martiny, A. C., FriasLopez, J., Zinser, E. R., and Chisholm, S. W.: Temporal dynamics of Prochlorococcus ecotypes in the Atlantic and Pacific oceans, ISME J., 4, 1252-1264, 2010.

Mann, E. L., Ahlgren, N., Moffett, J. W., and Chisholm, S. W.: Copper toxicity and cyanobacteria ecology in the Sargasso Sea, Limnol. Oceanogr., 47, 976-988, 2002.

Marie, D., Brussaard, C., Partensky, F., and Vaulot, D.: Flow cytometric analysis of phytoplankton, bacteria and viruses, in: Current Protocols in Cytometry, edited by: Sons, J. W., International Society for Analytical Cytology, 11.11.11-11.11.15., 1999.

Marie, D., Zhu, F., Balagué, V., Ras, J., and Vaulot, D.: Eukaryotic picoplankton communities of the Mediterranean Sea in summer assessed by molecular approaches (DGGE, TTGE, QPCR), FEMS Microbiol. Ecol., 55, 403-415, 2006.

Martiny, A. C., Tai, A. P., Veneziano, D., Primeau, F., and Chisholm, S. W.: Taxonomic resolution, ecotypes and the biogeography of Prochlorococcus, Environ. Microbiol., 11, 823832, 2009.

Marty, J.-C., Chiavérini, J., Pizay, M. D., and Avril, B.: Seasonal and interannual dynamics of nutrients and phytoplankton pigments in the western Mediterranean Sea at the DYFAMED timeseries station (1991-1999) Deep Sea Res. Pt. II, 49, 1965-1985, 2002 . 
Massana, R., Balague, V., Guillou, L., and Pedros-Alio, C.: Picoeukaryotic diversity in an oligotrophic coastal site studied by molecular and culturing approaches, FEMS Microbiol. Ecol., 50, 231-243, 2004.

Matsen, F. A., Kodner, R. B., and Armbrust, E. V.: Pplacer: linear time maximum-likelihood and Bayesian phylogenetic placement of sequences onto a fixed reference tree, BMC Bioinfo., 11, 538, 2010.

Mazard, S., Ostrowski, M., Partensky, F., and Scanlan, D. J.: Multiquence analysis, taxonomic resolution and biogeography of marine Synechococcus, Environ. Microbiol., http://onlinelibrary. wiley.com/doi/10.1111/j.1462-2920.2011.02514.x/full, 2011.

Moutin, T., Thingstad, T. F., Van Wambeke, F., Marie, D., Slawyk, G., Raimbault, P., and Claustre, H.: Does competition for nanomolar phosphate supply explain the predominance of the cyanobacterium Synechococcus?, Limnol. Oceanogr., 47, 15621567, 2002.

Moutin, T., Van Wambeke, F., and Prieur, L.: The Biogeochemistry from the Oligotrophic to the Ultraoligotrophic Mediterranean (BOUM) experiment, Biogeosciences Discuss., 8, 8091-8160, doi:10.5194/bgd-8-8091-2011, 2011.

Needleman, S. B. and Wunsch, C. D.: A general method applicable to the search for similarities in the amino acid sequence of two proteins, J. Mol. Biol., 48, 443-453, 1970.

Obernosterer, I., Christaki, U., Lefèvre, D., Catala, P., Van Wambeke, F., and Lebaron, P.: Rapid bacterial mineralization of organic carbon produced during a phytoplankton bloom induced by natural iron fertilization in the Southern Ocean., Deep Sea Res. Pt. II, 55, 777-789, 2008.

Olson, R. J., Chisholm, S. W., Zettler, E. R., and Armbrust, E. V.: Analysis of Synechococcus pigment types in the sea using single and dual beam flow cytometry, Deep Sea Res. Pt. I, 35, 425-440, 1988.

Olson, R. J., Zettler, E. R., Armbrust, E. V., and Chisholm, S. W.: Pigment, size and distribution of Synechococcus in the North Atlantic and Pacific oceans, Limnol. Oceanogr., 35, 45-58, 1990.

Ostrowski, M., Mazard, S., Tetu, S. G., Phillippy, K., Johnson, A., Palenik, B., Paulsen, I. T., and Scanlan, D. J.: PtrA is required for coordinate regulation of gene expression during phosphate stress in a marine Synechococcus, ISME J., 4, 908-921, 2010.

Palenik, B., Brahamsha, B., Larimer, F. W., Land, M., Hauser, L., Chain, P., Lamerdin, J., Regala, W., Allen, E. E., McCarren, J., Paulsen, I., Dufresne, A., Partensky, F., Webb, E. A., and Waterbury, J.: The genome of a motile marine Synechococcus, Nature, 424, 1037-1042, 2003.

Palenik, B., Ren, Q. H., Dupont, C. L., Myers, G. S., Heidelberg, J. F., Badger, J. H., Madupu, R., Nelson, W. C., Brinkac, L. M., Dodson, R. J., Durkin, A. S., Daugherty, S. C., Sullivan, S. A., Khouri, H., Mohamoud, Y., Halpin, R., and Paulsen, I. T.: Genome sequence of Synechococcus CC9311: Insights into adaptation to a coastal environment, Proc. Natl Acad. Sci. USA., 103, 13555-13559, 2006.

Partensky, F., Blanchot, J., Lantoine, F., Neveux, J., and Marie, D.: Vertical structure of picophytoplankton at different trophic sites of the tropical northeastern Atlantic Ocean, Deep Sea Res. Pt. I, 43, 1191-1213, 1996.

Partensky, F., Blanchot, J., and Vaulot, D.: Differential distribution and ecology of Prochlorococcus and Synechococcus in oceanic waters: a review, in: Marine Cyanobacteria, edited by: Charpy,
L. and Larkum, A., Musée Océanographique, Monaco, 457-475, 1999.

Partensky, F. and Garczarek, L.: Prochlorococcus: Advantages and limits of minimalism, Ann. Rev. Mar. Sci., 2, 305-331, 2010.

Paytan, A., Mackey, K. R., Chen, Y., Lima, I. D., Doney, S. C., Mahowald, N., Labiosa, R., and Post, A. F.: Toxicity of atmospheric aerosols on marine phytoplankton, Proc. Natl. Acad. Sci. USA., 106, 4601-4605, 2009.

Posada, D.: jModelTest: phylogenetic model averaging, Mol. Biol. Evol., 25, 1253-1256, 2008.

Posada, D.: Selection of models of DNA evolution with jModelTest, Meth. Mol. Biol., 537, 93-112, 2009.

Pujo-Pay, M., Conan, P., Oriol, L., Cornet-Barthaux, V., Falco, C., Ghiglione, J.-F., Goyet, C., Moutin, T., and Prieur, L.: Integrated survey of elemental stoichiometry $(\mathrm{C}, \mathrm{N}, \mathrm{P})$ from the western to eastern Mediterranean Sea, Biogeosciences, 8, 883899, doi:10.5194/bg-8-883-2011, 2011.

Raimbault, P., Slawyk, G., Coste, B., and Fry, J.: Feasibility of using an automated colorimetric procedure for the determination of seawater nitrate in the 0 to $100 \mathrm{nM}$ range: Examples from field and culture, Mar. Biol., 104, 347-351, 1990.

Ras, J., Uitz, J., and Claustre, H.: Spatial variability of phytoplankton pigment distributions in the subtropical South Pacific Ocean: comparison between in situ and modelled data, Biogeosciences, 5, 353-369, 2008,

http://www.biogeosciences.net/5/353/2008/.

Reynolds, R. W., Rayner, N. A., Smith, T. M., Stokes, D. C., and Wang, W.: An improved in situ and satellite SST analysis for climate, J. Clim., 15, 1609-1625, 2002.

Rocap, G., Distel, D. L., Waterbury, J. B., and Chisholm, S. W.: Resolution of Prochlorococcus and Synechococcus ecotypes by using 16S-23S ribosomal DNA internal transcribed spacer sequences, Appl. Environ. Microbiol., 68, 1180-1191, 2002.

Rocap, G., Larimer, F. W., Lamerdin, J., Malfatti, S., Chain, P., Ahlgren, N. A., Arellano, A., Coleman, M., Hauser, L., Hess, W. R., Johnson, Z. I., Land, M., Lindell, D., Post, A. F., Regala, W., Shah, M., Shaw, S. L., Steglich, C., Sullivan, M. B., Ting, C. S., Tolonen, A., Webb, E. A., Zinser, E. R., and Chisholm, S. W.: Genome divergence in two Prochlorococcus ecotypes reflects oceanic niche differentiation, Nature, 424, 1042-1047, 2003.

Rusch, D. B., Martiny, A. C., Dupont, C. L., Halpern, A. L., and Venter, J. C.: Characterization of Prochlorococcus clades from iron-depleted oceanic regions, Proc. Natl. Acad. Sci. USA, 107, 16184-16189, 2010.

Saaroni, H., Ziv, B., Edelson, J., and Alpert, P.: Long-term variations in summer temperatures over the Eastern Mediterranean, Geophys. Res. Lett., 30, doi:10.1029/2003GL017742, 2003.

Scanlan, D. J., Ostrowski, M., Mazard, S., Dufresne, A., Garczarek, L., Hess, W. R., Post, A. F., Hagemann, M., Paulsen, I., and Partensky, F.: Ecological genomics of marine picocyanobacteria, Microbiol. Mol. Biol. Rev., 73, 249-299, 2009.

Somot, S., Sevault, F., and Déqué, M.: Transient climate change scenario simulation of the Mediterranean Sea for the Twenty-first century using a high-resolution ocean circulation model, Clim. Dynam., 27, 851-879, 2006.

Stamatakis, A.: RAxML-VI-HPC: maximum likelihood-based phylogenetic analyses with thousands of taxa and mixed models, Bioinformatics, 22, 2688-2690, 2006. 
Tai, V. and Palenik, B.: Temporal variation of Synechococcus clades at a coastal Pacific Ocean monitoring site, ISME J., 3, 903-915, 2009.

Tai, V., Burton, R. S., and Palenik, B.: Temporal and spatial distributions of marine Synechococcus in the Southern California Bight assessed by hybridization to bead-arrays Mar. Ecol. Prog. Ser., 426, 133-147, 2011.

Tanaka, T., Zohary, T., Krom, M. D., Lawe, C. S., Pitta, P., Psarra, S., Rassoulzadegan, F., Thingstad, T. F., Tselepides, A., Woodward, E. M. S., Flaten, G. A. F., Skjoldal, E. F., and Zodiatis, G.: Microbial community structure and function in the Levantine Basin of the eastern Mediterranean, Deep Sea Res. Pt. I, 54, 1721-1743, 2007.

Tanaka, T., Thingstad, T. F., Christaki, U., Colombet, J., CornetBarthaux, V., Courties, C., Grattepanche, J.-D., Lagaria, A., Nedoma, J., Oriol, L., Psarra, S., Pujo-Pay, M., and Van Wambeke, F.: Lack of P-limitation of phytoplankton and heterotrophic prokaryotes in surface waters of three anticyclonic eddies in the stratified Mediterranean Sea, Biogeosciences, 8, 525-538, doi:10.5194/bg-8-525-2011, 2011

Ternon, E., Guieu, C., Ridame, C., L'Helguen, S., and Catala, P.: Longitudinal variability of the biogeochemical role of Mediterranean aerosols in the Mediterranean Sea, Biogeosciences, 8, 1067-1080, doi:10.5194/bg-8-1067-2011, 2011.

Tetu, S. G., Brahamsha, B., Johnson, D. A., Tai, V., Phillippy, K., Palenik, B., and Paulsen, I. T.: Microarray analysis of phosphate regulation in the marine cyanobacterium Synechococcus sp. WH8102, ISME J., 3, 835-849, 2009.

Thompson, J. R., Marcelino, L. A., and Polz, M. F.: Heteroduplexes in mixed-template amplifications: formation, consequence and elimination by "reconditioning PCR", Nucl. Acids Res., 30, 2083-2088, 2002.

Toledo, G., Palenik, B., and Brahamsha, B.: Swimming marine Synechococcus strains with widely different photosynthetic pigment ratios form a monophyletic group, Appl. Environ. Microbiol., 65, 5247-5251, 1999.
Toledo, G. and Palenik, B.: A Synechococcus serotype is found preferentially in surface marine waters, Limnol. Oceanogr., 48, 1744-1755, 2003.

West, N. J. and Scanlan, D. J.: Niche-partitioning of Prochlorococcus populations in a stratified water column in the eastern north Atlantic ocean, Appl. Environ. Microbiol., 65, 2585-2591, 1999.

West, N. J., Lebaron, P., Strutton, P. G., and Suzuki, M. T.: A novel clade of Prochlorococcus found in high nutrient low chlorophyll waters in the South and Equatorial Pacific Ocean, ISME J., 5, 933-944, 2010.

Zinser, E. R., Coe, A., Johnson, Z. I., Martiny, A. C., Fuller, N. J., Scanlan, D. J., and Chisholm, S. W.: Prochlorococcus ecotype abundances in the North Atlantic Ocean as revealed by an improved quantitative PCR method, Appl. Environ. Microbiol., 72, 723-732, 2006.

Zinser, E. R., Johnson, Z. I., Coe, A., Karaca, E., Veneziano, D., and Chisholm, S. W.: Influence of light and temperature on Prochlorococcus ecotype distributions in the Atlantic Ocean, Limnol. Oceanogr., 52, 2205-2220, 2007.

Zubkov, M. V., Sleigh, M. A., and Burkill, P. H.: Assaying picoplankton distribution by flow cytometry of underway samples collected along a meridional transect across the Atlantic Ocean, Aquat. Microb. Ecol., 21, 13-20, 2000.

Zwirglmaier, K., Heywood, J. L., Chamberlain, K., Woodward, E. M. S., Zubkov, M. V., and Scanlan, D. J.: Basin-scale distribution patterns lineages in the Atlantic Ocean, Environ. Microbiol., 9, 1278-1290, 2007.

Zwirglmaier, K., Jardillier, L., Ostrowski, M., Mazard, S., Garczarek, L., Vaulot, D., Not, F., Massana, R., Ulloa, O., and Scanlan, D. J.: Global phylogeography of marine Synechococcus and Prochlorococcus reveals a distinct partitioning of lineages among oceanic biomes, Environ. Microbiol., 10, 147-161, 2008. 